GREYFIELD REDEVELOPMENT IN THE GREATER TORONTO AREA:

STRATEGIES TO OVERCOME BARRIERS

By

James Greenfield, BA (hons),

Wilfrid Laurier University 2011

\begin{abstract}
A Major Research Paper
Presented to Ryerson University

In partial fulfillment of the requirements for the degree of

Master of Planning

In

Urban Development
\end{abstract}

Toronto, Ontario, Canada, 2013

(C) James Greenfield 2013 
I hereby declare that I am the sole author of this Major Research Paper. This is a true copy of the Major Research Paper, including any required final revisions, as accepted by my examiners.

I authorize Ryerson University to lend this paper to other institutions or individuals for the purpose of scholarly research.

I further authorize Ryerson University to reproduce this Major Research Paper by photocopying or by other means, in total or in part, at the request of other institutions or individuals for the purpose of scholarly research.

I understand that my Major Research Paper may be made electronically available to the public. 


\title{
GREYFIELD REDEVELOPMENT IN THE GREATER TORONTO AREA: \\ STRATEGIES TO OVERCOME BARRIERS
}

(C) James Greenfield, 2013

\author{
Master of Planning \\ In \\ Urban Development \\ Ryerson University
}

\begin{abstract}
In 2006, the introduction of the Places to Grow Act required municipalities to meet a $40 \%$ intensification target through infill development. This has transformed the development industry as many underutilized sites, such as Greyfields, are prime locations for mixed-use and densification. Although many developers have not harnessed the potential of Greyfield redevelopment as barriers exist, which has led to continued Greenfield development and urban sprawl. This paper, through a literature review, case study analysis, and key informant interviews, examines existing barriers to Greyfield redevelopment. Findings from the study were than applied to a Greyfield site that has immense opportunity for redevelopment. A preliminary site plan proposal and recommendations are presented to illustrate strategies that should be adopted to ensure successful redevelopment.
\end{abstract}

KEY WORDS: Greyfields, Infill, Intensification, Places to Grow, Redevelopment 


\section{Acknowledgements}

It is with immense gratitude that I acknowledge the support and help of my Professor, Dr. Chris De Sousa for giving me this opportunity and providing insight, patience, and expertise. Without his guidance and persistent help, this paper would not have been possible. I would also like to thank my second reader Andrew Hordylan, for his support and guidance through this process. I value our long academic discussions, which enhanced the depth of this paper. 
$\begin{array}{ll}1.0 \text { Introduction } & 1\end{array}$

2.0 Brownfields and Greyfields Defined 4

3.0 Why Greyfields? 9

3.1 Benefits of Greyfields $\quad 10$

4.0 Greyfield Redevelopment Models 13

4.1 Mixed-Use Redevelopment 13

4.2 Adaptive Reuse 13

4.3 Single Use Redevelopment 14

4.4 Reinvested Mall 14

4.5 Mall Reposition $\quad 15$

$\begin{array}{ll}\text { 5.0 Literature Review } & 16\end{array}$

$\begin{array}{ll}\text { 6.0 Methodology } & 19\end{array}$

$\begin{array}{ll}\text { 7.0 Case Study Context } & 23\end{array}$

8.0 Case Studies $\quad 25$

8.1 Olde Thornhill Village, Markham, Ontario 25

8.1.1 Site Context 25

8.1.2 Site Description $\quad 26$

8.1.3 Site History 29

8.1.4 Redevelopment Proposal 31

8.1.5 Redevelopment Barriers 36

8.1.6 Summary 38

8.2 Humbertown Shopping Centre, Etobicoke, Ontario $\quad 41$

8.2.1 Site Context 41

8.2.2 Site Description $\quad 42$

8.2.3 Site History 46

8.2.4 Redevelopment Proposal 48

8.2.5 Redevelopment Barriers $\quad 54$

8.2.6 Summary 56

$\begin{array}{ll}9.0 \text { Analysis } & 59\end{array}$

10.0 Potential Greyfield Redevelopment Site $\quad 65$

10.1 5799-5915 Yonge Street, Toronto 65 
10.2 Site Context

10.3 Site Description

10.4 Redevelopment Plan

10.5 Planning Rationale

11.0 Recommendations

75

12.0 Works Cited

79

Primary Sources

79

Literature Sources

79

Photo Sources

82 
Table 1: Humbertown Redevelopment Proposal Summary

List of Figures

Figure 1: Map of the Greater Toronto Area- Olde Thornhill Village

Figure 2 Olde Thornhill Village, Markham: Building Footprints

Figure 3: Olde Thornhill Village: Site Context

Figure 4: Olde Thornhill Village- Figure Ground with Roads

Figure 5: Historic Photo with Existing Office Building

Figure 6: Historic Photo: Large Parking Lot with Apartments to the North

Figure 7: Olde Thornhill Village- Phase One Site Plan

Figure 8: Stacked Townhomes above Parking Structure

Figure 9: Street Design with Pedestrian Walkway- Facing South

Figure 10: Entrance from John Street- Facing North

Figure 11: Private Park for Residents

Figure 12: Townhome Design- Phase 1 (left) and Phase 2 (right)

Figure 13: Humbertown Shopping Centre Figure Ground

Figure 14: Humbertown Shopping Centre

Figure 15: Humbertown Shopping Centre- Surrounding Properties

Figure 16: Adjacent 17-storey Apartment Building- North of Humbertown

Figure 17: Apartment Building - East of Humbertown

Figure 18: Humbertown Shopping Centre- Office Component 
Figure 19: Humbertown Shopping Centre- LCBO with Bulk Barn in Background

Figure 20: North York Existing Greyfield- 5799-5915 Yonge Street

Figure 21: Figure Ground of 5799-5915 Yonge Street

Figure 22: Residential Condominiums at Finch Station

Figure 23: Existing Commercial Office Component Onsite

Figure 24: Commercial Tenants Onsite with Excessive Parking

Figure 25: Potential Site Plan Proposal

Figure 26: Massing and Surrounding Heights- Facing Southwest

Figure 27: Yonge Street Entrance and Street Frontage- Facing South

Figure 28: Illustrates Surface Parking, Park Space and Internal Traffic Circulation

Figure 29: Height Comparison with Residential Buildings at Finch Subway Station 


\subsection{Introduction}

North American urban growth is typically referred to as urban sprawl; the trend to develop rural land, commonly identified as Greenfields. Steady immigration rates since the late 1940's have driven this sprawl throughout the Greater Toronto Area (GTA) prompting continued loss of prime agricultural land and increases to municipal capital expenditures. Urban sprawl can often be attributed to market demand, as many Canadian families seek to own a single-family detached home with a backyard. Regardless of the true reason for urban sprawl, there are several drawbacks such as loss of habitat, woodlots, farmland, and biodiversity.

There is need to shift away from Greenfield development towards more sustainable growth to limit municipal capital expenditures. It is now increasingly necessary to intensify within the urban boundary. Ensuring that underutilized lands within city or municipal boundaries are developed is essential to reducing the loss of farmland. Underutilized sites can normally be found along arterial or major roads where their current use does not live up to the site's potential. These prospective sites should be intensified instead of developing on farmland because this type of growth is more sustainable long term. Recently the Ontario government has attempted to mitigate 
continued urbanization into highly valuable farmland with the introduction of such legislation as the Greenbelt Plan \& Act (2005) and the Growth Plan for the Greater Golden Horseshoe (2006). These legislative tools promote a permanent boundary surrounding the GTA that enables minimal growth on Greenfields. A more viable growth option is through the intensification or densification within the current municipal urban boundary, as set out by the Growth Plan, will alleviate concerns regarding sprawl and expenditure. Redevelopment of existing underutilized sites is a sustainable strategy to increase density and construct according to highest and best land use. This legislation has effectively protected prime agricultural land and requires each municipality to accommodate $40 \%$ of all new growth inside the urban growth boundary by intensifying within built up areas (GPGGH, 2006). This will encourage infill development along major arterial roads and within current municipal boundaries, to ensure efficiency and longevity of future growth.

This paper will seek to address barriers that limit redevelopment of Greyfields by examining existing literature and evaluating two case studies in the GTA. These case studies will inform the selection of a Greyfield site that is a prime location for redevelopment and provide a preliminary site plan proposal indicating a successful strategy to intensifying the property. To guide this research, the following questions were considered:

- What are the barriers to Greyfield redevelopment compared to 
Greenfield development in the GTA?

- Why do some Greyfield redevelopments fail and others succeed in the Greater Toronto Area?

- Are some Greyfield sites more viable than others based on location?

- What redevelopment strategy produces a successful outcome?

The report is divided into several sections. The following chapter will discuss the current framework of Greyfield redevelopment in Ontario as well as compared to the United States. This section will also investigate the involvement of the Congress for New Urbanism and how Greyfields are defined. The next section will discuss the importance of Greyfield redevelopment, as well as associated benefits and potential redevelopment models that can be applied to Greyfields. A literature review follows, which will provide a comprehensive evaluation of existing research. The following chapter incorporates an overview of case studies in the GTA. Key informant interviews were used to identify barriers that exist in the redevelopment process for each case study. Following this section, a detailed analysis and summary of the case studies is presented which includes redevelopment barriers, as well as strategies to overcome these issues. Furthermore, the final case study discussed provides strategies to redevelop for a Greyfield site. Finally, the report concludes with recommendations for future redevelopment strategies and improvements. 


\subsection{Brownfields and Greyfields Defined}

It is important to understand the difference between a Brownfield versus a Greyfield, both defined through the Congress for the New Urbanism (Sobel, 2002). The congress strives to reduce urban sprawl by advocating for changes in government policy to promote the creation of complete communities. Moreover, they encourage the need for communities to embrace walkability through an integration of landuses while providing a range of housing types and jobs. Brownfield sites are normally found within the urban boundary, as they were once important industrial employment lands. Although these sites can contribute to infill development, there are many financial liability risks associated with them due to environmental concerns stemming from contaminated soil to groundwater contamination, transfer of dense nonaqueous fluids further spreading the original contaminate. Greyfields are found in built up urban areas and are one of the best choices for intensification because it utilizes sites that are no longer profitable, are not significantly contaminated which reduces financial risk and are normally found in the form of old retail plazas, office parks, abandoned municipal properties and parking lots. Greyfields tend to have a greater opportunity for redevelopment compared to Brownfields because they can normally be found along arterial roads, have accessibility to public transit and exist on large parcels. These attributes serve as a catalyst to redevelop as the location and lot size promote a variety of development options. Greyfields that are 
situated along arterial roads most often have as of right zoning permissions for mixed-use development that include residential, office and retail.

The Congress for New Urbanism designates a site as a Greyfield once the cost of leasable square footage per year falls below $\$ 150$ (Sobel, 2002). This definition is the American standard of Greyfields that could be applied in Ontario, though very few sites in the GTA have vacancy rates as defined by the Congress for New Urbanism. In this case, a broader definition of Greyfield sites should be considered in Ontario where age, surrounding uses, and location are factors that identify Greyfields.

Regardless of the previous land use of Greyfield sites, a single stakeholder most often owns these large parcels. The potential redevelopment of Greyfields is much greater as one landowner has the ability to construct a comprehensive development without input from other stakeholders. The acquisition of the property would also be more lucrative as developers realize they do not need to expropriate several properties in order to develop.

Greyfield redevelopment tends to have a positive affect on surrounding real estate through the construction of a complete community, attracting new residents to shop in the neighbourhood, creating more park space and 
providing a variety of new opportunities for existing residents to enjoy. These developments will also increase surrounding property values, as its previous use was less desirable, since this new configuration of a mixed-use community coupled with transit oriented development will attract a variety of purchasers (De Sousa, 2006). Such a development would come in the form of a walkable neighbourhood, with shopping opportunities from groceries to drug stores and everything in between. This type of community is an example of Smart Growth, as they seek to build live-work-play communities with public transportation options that use existing infrastructure through increased density (Bucher, 2002).

Greyfield redevelopment is considered a Smart Growth option because it creates whole communities that can prosper as a self-sustained unit. A diverse mixed-use community with pedestrian amenities allow for a reduction of car ownership and increased walkability (Gilder-Busatti, 2007; Bucher, 2002). Many retail plazas and malls become Greyfield sites due to their lack of retail diversity or simply the placement does not cast a large enough retail catchment. However, some retail plazas can be characterized as being underutilized without issues of profitability but are located at a prime location, resulting in an opportunity for redevelopment.

Greyfield sites in Ontario are unlike American Greyfields because 
commercial vacancy rates in the United States (US) are much greater, leading to extremely blighted regions with little inhabitance. This can be attributed to the number of shopping centres found in the US compared to Canada. In a 2012 study, it was found that the US has 2,370 square feet of retail for every 100 people while Canada only has 1,453 square feet (Shaw, 2012). Moreover, the performance of retail shopping centres in Canada were found to be stronger; in 2011 sales per square foot was 50\% higher compared to the US (2012). This indicates that the US retail market can be characterized with having an oversupply of retail shopping centres. There is also severe competition in the US. In 2001, PricewaterhouseCoopers conducted a study which identified an average of 2.3 million square feet of retail space can be found in a five-mile radius of shopping centres (PWC, 2001). This signifies that there is an overall saturation of retail space in the US, which contributes to high vacancy rates. In addition, the recent downturn in the American economy has also led to an increase of vacancy rates found in retail plazas, shopping centres and regional malls. Ontario on the other hand, have Greyfields with lower vacancy rates but are nonetheless viable for redevelopment due to their strategic location, large footprint, and underutilized use. Ontario Greyfields should not be classified similarly to American Greyfields since their vacancy rates cannot be compared, although there are retail sites in Ontario that are underutilized. 
Ontario contains many Greyfield sites. Important steps to creating a framework for future redevelopment strategies in Ontario will be to create a new and refined definition of a Greyfield. This is necessary because Greyfields encompass more complexities than simply vacancy rates. A variety of issues need to be addressed through a series of parameters such as the age of the structure, assessment value, Gross Floor Area, type of employment, vacancy rate and surrounding land uses. As Greyfields are not as severely derelict in Ontario as they are found in the United States, it is essential to identify the parameters for viable Ontario Greyfield redevelopment. This framework will also support the final case study, located at 5799-5915 Yonge Street, Toronto, which will identify strategies for redevelopment through a preliminary site plan. 


\subsection{Why Greyfields?}

The Greenbelt Plan (2005) and Growth Plan for the Greater Golden

Horseshoe (2006) have contributed to the need to build within the current urban growth boundary through infill development, though many issues remain. Greenfield development has continued to be utilized in many municipalities that abut rural farmland, hence the common vernacular of "sprawl". For developers, increased land costs have shifted their bottom-line and ultimately their return, leading developers to design and construct a mix of built forms and higher density subdivisions through townhomes and semidetached dwellings in order to maximize revenues. The Official Plans of municipalities encourage a wide range of housing options to ensure that citizens have the opportunity to live comfortably, regardless of their household income. Greyfield redevelopment provides an opportunity for municipalities to build suitable development types, intensify infill regions, and reduce the construction of car-oriented suburbs. Utilizing Greyfield redevelopment may increase public transportation ridership since their proximity to transit infrastructure enable citizens the opportunity to commute by subway or bus. Efficiency can also be found through the densification of infill regions to reduce the strain of building servicing infrastructure for municipalities. Constructing new sewers and water mains is a costly venture and with continued senior government downloading, municipalities are unable to provide these services as urban sprawl continues 
to produce fiscal constraints. Greyfield redevelopment provides many opportunities for citizens to take advantage of public transit and have the ability to walk to local amenities.

A large proportion of Greyfield redevelopment strategies are through the implementation of Smart Growth initiatives. Smart Growth principles include a mix of uses, compact building design, walkability, sense of place, range of housing choices, public transportation opportunities and preservation of farmland (Smart Growth Network, 2001). These initiatives tend to be used in Greyfield projects because implementation is made easier due to their locations and through sustainable intensification. This enables further Smart Growth strategies to be used because a completely sustainable community can be created to promote walkability.

\subsection{Benefits of Greyfields}

Greyfields have a variety of benefits associated with their redevelopment. The benefits that exist can be closely associated with Brownfields but to a lesser extent. The benefits of Brownfield development compared to Greenfield development are substantial. This can be attributed to the economic, environmental, and social improvements that can be found when redeveloping Brownfields (De Sousa, 2002). Similarly, Greyfields will also have a positive effect on the surrounding neighbourhood, although existing literature does not provide evidence that demonstrates these improvements. 
Brownfield issues can be correlated with Greyfields; as such there benefits will be comparable. Greyfield benefits include:

- Reduction of urban sprawl due to intensification

- Utilization of existing servicing infrastructure

- Less dependence on the automobile

- Provide local job opportunities

- Increase diversity of landuses

- Improve sight lines by reducing visual blight

- Opportunity for mixed-use development

- Increase surrounding property values

(McKay, 2007; Sobel, 2002; Province of Ontario, 2006; Chilton, Undated; CNU, 2005)

Several benefits involve Greyfield redevelopment that will not be recognizable until years after construction. Improved traffic circulation, for example, can often only be identified following years of operation because the introduction of residential units increases the number of onsite parking requirements, which will place a greater circulation burden on abutting streets and access points.

If the commercial units are successful, they will undoubtedly produce greater traffic onsite; it is this interaction between residential and retail users, which will indicate if traffic circulation needs are adequate and can take several years to be attained. Greyfields have the ability to shape neighbourhoods due to their size and location along arterial roadways, though they also can have a diversely negative effect if they are not designed and redeveloped correctly. In order for there to be positive results in the surrounding neighbourhood, 
Greyfield redevelopment must be designed with care by utilizing interactive public consultations and ensuring proper site plan design. 


\subsection{Greyfield Redevelopment Models}

There are many different Greyfield redevelopment models that can be utilized on sites with existing structures, though each instance will present various constraints. The model option with the greatest long-term profitability is the mixed-use model but this will not always be feasible in every situation (CNU, 2005). The following redevelopment models have been identified within existing literature.

\subsection{Mixed-Use Redevelopment}

This redevelopment model requires the complete or partial demolition of the existing mall. The site will be then redesigned to incorporate some or all of the following uses: commercial retail, commercial office, residential, open space, and employment uses. The site will have a variety of multistory buildings that contain multiple uses within its structure. Mixed-use redevelopments will encompass private street patterns, pedestrian oriented sidewalk design and include open space and/or community facilities (CNU, 2005). Structured parking is normally used to allow greater densities to be reached and increased lot coverage (McKay, 2007). Town centre design is applied onsite to improve mixed-use connectivity, walkability through small block size and human scale massing to increase pedestrian comfort.

\subsection{Adaptive Reuse}

This redevelopment model will utilize the existing structure to accommodate a single new use or several uses. A renovation of the interior and exterior of 
the structure is conducted to create efficient space for churches, institutional uses or dwelling units (CNU, 2005). This model typically eliminates or greatly reduces the retail component, as the site has been deemed unprofitable due to market restrictions, limited access, or strong local competition (McKay, 2007).

\subsection{Single Use Redevelopment}

Complete demolition of the structure is necessary in this scenario, in order to accommodate a new single use. This redevelopment model seeks to intensify the existing site with commercial office, retail, big-box retail, employment uses or strictly residential. Single use redevelopment provides limited risk to Greyfield owner's compared to multi-use redevelopments because the introduction of multi-uses can present a wide range of problems that may hinder redevelopment. Owner's are more likely to choose this scenario if they wish to redevelop quickly and avoid a potentially lengthy planning process and construction period.

\subsection{Reinvested Mall}

This scenario involves the renovation of the existing structure to revitalize its appearance in order to attract new tenants, make changes to the tenant mix or attracts new customers; a demographic change in the regional or local catchment area will often spur reinvestment onsite. Improvements to the design of the building may include new entrances, improved food services, 
new façade, modern interior finishing's and enhanced lighting and signage (CNU, 2005). A market study analysis should be conducted before mall reinvestment because interior design improvements may only boost retail sales temporarily and would require a more intense redevelopment strategy (2005).

\subsection{Mall Reposition}

The redevelopment strategy, similar to reinvestment, involves improvements to the existing building through additions that may include restaurants, more retail space or entertainment uses. This scenario can include renovations to improve failing retail portions of the site by introducing new non-residential uses to create a multi-use complex (McKay, 2007). Mall repositioning may also incorporate enhanced open spaces and pedestrian walkways between land uses to encourage connectivity.

The redevelopment potential for Greyfield sites vary depending on the location, as such not all models are achievable. The mixed-use redevelopment model can dramatically improve the surrounding neighbourhood but other redevelopment models can still have a positive effect. 


\subsection{Literature Review}

There is limited Greyfield literature, especially in the Canadian context. Sobel (2002) provides a broad overview of the economic viability of Greyfield sites throughout the United States, as well as case studies, though this does not offer clear insight into Ontario since American retail has continued to spiral downward. Although there is inadequate Greyfield literature in Ontario there is however exceptional information on vacancy rates, as well as the Greater Toronto Area produced by the Centre for the Study of Commercial Activity (Hernandez, 2011; Gomez-Insausti, Erguden \& Jones, 2000). The transformation of retail plazas has altered greatly in the past decade, especially with the emergence of online shopping. Forcing retailers to adapt to changing markets in Toronto, though for the most part Toronto's retail remains strong and diverse between the years of 1996-2005 (Hernandez, Helik and Moore, 2006). This data should inform the types of retail that still exists in Toronto as well as the location of potential Greyfield sites. Hernandez has produced vacancy rate data from 2005-2009 in the GTA and an analysis of this information will provide insight into trends for the future of retail (Hernandez, 2009).

The most significant portion of literature pertaining to Greyfields involves redevelopment model choices and mixed-use communities. Design approaches of Greyfields are well researched, especially retrofitting sites for mixed-use 
development and pedestrian oriented communities (Alfonza, 2007; Bodzin, 2003; Mandel, 2005; Vasilyan, 2011; Webb, 2003). Understanding the integration of a Greyfield site plan into the surrounding context is important and needs to be taken into account for proper implementation. The correct balance of landuses should be addressed in a manner that allows for developer incentive while comprising community support. Implementing a redevelopment scheme with residential use is challenging and as such, the Planning Advisory Service Report of 2009 has created an in-depth guide to facilitating this model choice. As most of the redevelopment choices tend to deal with some sort of residential component, this report will be of great benefit to the implementation strategies.

There are some professional sources that investigate practical municipal approaches and policy incentives within Ontario (CMHC, 2009). The Canadian Mortgage Housing Corporation has also produced many case study investigations throughout Ontario, including the Olde Thornhill Village redevelopment in Markham. Analysis of the redevelopment proposal identifies the key aspects that went into the successful integration of the residential use (CMHC, 2008). A large part of literature examines Markham's City staff initiatives and visioning Thornhill Secondary Plan (CMHC, 2009). With the continued emergence of big box retailers, municipalities may need to prevent retail plaza blight from occurring through specific zoning 
measures. Site cap zoning may be a necessary strategy for municipalities to prevent large retailers from taking over the local retail market (Sochar, 2008). Some of the literature that exists to date can be identified as being obsolete due to the economic stability of the real estate market, which has transformed the development industry. It is necessary to investigate a thorough analysis of current Greyfield redevelopment case studies to improve the success of future proposals and ensure that all stakeholders approve new development. 


\subsection{Methodology}

This paper will identify the current state of Greyfield redevelopment in Ontario and investigate potential barriers. An assessment of the current state of Greyfields in the GTA will be undertaken to identify the potential implementation of an Ontario Greyfield standard. A new definition of a Greyfield should be acknowledged in the Province as redevelopment continues to occur. As vacancy rates are not a reliable source for the redevelopment potential of a given site. There are many factors that can contribute in defining a Greyfield, and a more comprehensive classification needs to address Greyfields in Ontario.

Most literature relating to Greyfields tends to focus directly on the end product and urban design. The interaction that occurs during the redevelopment process between the municipality, the developer and the surrounding residents is often overlooked, and this facilitation needs to be documented to enhance the proposal process. The impeding issues and the initial proposal should be closely aligned, to ensure a speedy approval process for the developer as well as an accepted development by the neighbourhood. As such, it is important to investigate case studies that involve a project that is currently in the planning process, and evaluate a case study that has been deemed successful by stakeholders and the surrounding neighbourhood. 
Olde Thornhill Village, located in Markham, indicates the potential for Greyfield redevelopment in Ontario because it is was a successful undertaking that benefitted the City, the local residents, and the developer. The original proposal for this location was not well accepted by the local residents because the owner was planning to redevelop the site into a big box store. This application was ultimately appealed and resulted in denial by the Ontario Municipal Board. After this decision, the owner of the property submitted an additional proposal, which included a mix of uses with pedestrian oriented design; something that the City and local residents supported.

The Humbertown Shopping Centre, located within an existing Etobicoke neighbourhood in the City of Toronto, will provide insight into the current barriers that are being faced by the developer and the criticism from the surrounding neighbourhood. This redevelopment proposal has several concerns raised by Toronto City Staff such as its conformity to the Avenues and Mid-rise Building Guidelines. There are other issues that impede this planning proposal; as such, this case study will provide informative insight into existing barriers. This redevelopment proposal has not been approved and has already gone through a lengthy planning process with several 
alterations to the site plan based on public input.

Primary research will be utilized in this report to understand the complexities involved in the planning process of Greyfield redevelopment. For each Greyfield case study, key informant interviews will be conducted with a variety of stakeholders. Speaking directly with developers, private \& public planners, urban designers, and residents associations will help facilitate implementation strategies to overcome barriers of Greyfield redevelopment. Understanding techniques, successful consultation strategies, and redevelopment models that were used in Markham as well as Etobicoke will greatly benefit the feasibility of potential sites for redevelopment. This method was chosen as it directly informs strategies that future stakeholders can utilize because key informants understand the issues that were involved in the project. Using this method does present some limitations. As several key stakeholders that were involved in the redevelopment process were unwilling to participate in this study. Furthermore, the types of stakeholders that were interviewed for each case study did not consist of the same disciplines.

Some of the research questions have been investigated in the past, though tangible results have not been achieved. Many case studies in the United States have been used to identify Greyfield redevelopment model strategies 
to alleviate potential barriers. These case studies have a variety of implementation strategies that will support the successful redevelopment of future Greyfield redevelopments in the GTA found in this report. Utilizing historic case studies and the case studies presented in this report, will provide ample justification for the planning rationale and site plan proposal of a potential Greyfield redevelopment site in the GTA, found at 5799-5915 Yonge Street, Toronto. 


\subsection{Case Study Context}

The GTA is located on the northwestern shores of Lake Ontario, and is home to the provincial capital of Ontario. The GTA has a population of approximately 5.58 million and has grown $9.2 \%$ since 2006 (Statistics Canada, 2012b). Its continued growth can be attributed to mass immigration, which has also spurred its diverse and robust economy as well as urban development. Figure 1 below, indicates the location of Olde Thornhill Village in relation to other municipalities in the GTA.

Figure 1: Map of the Greater Toronto Area-Olde Thornhill Village

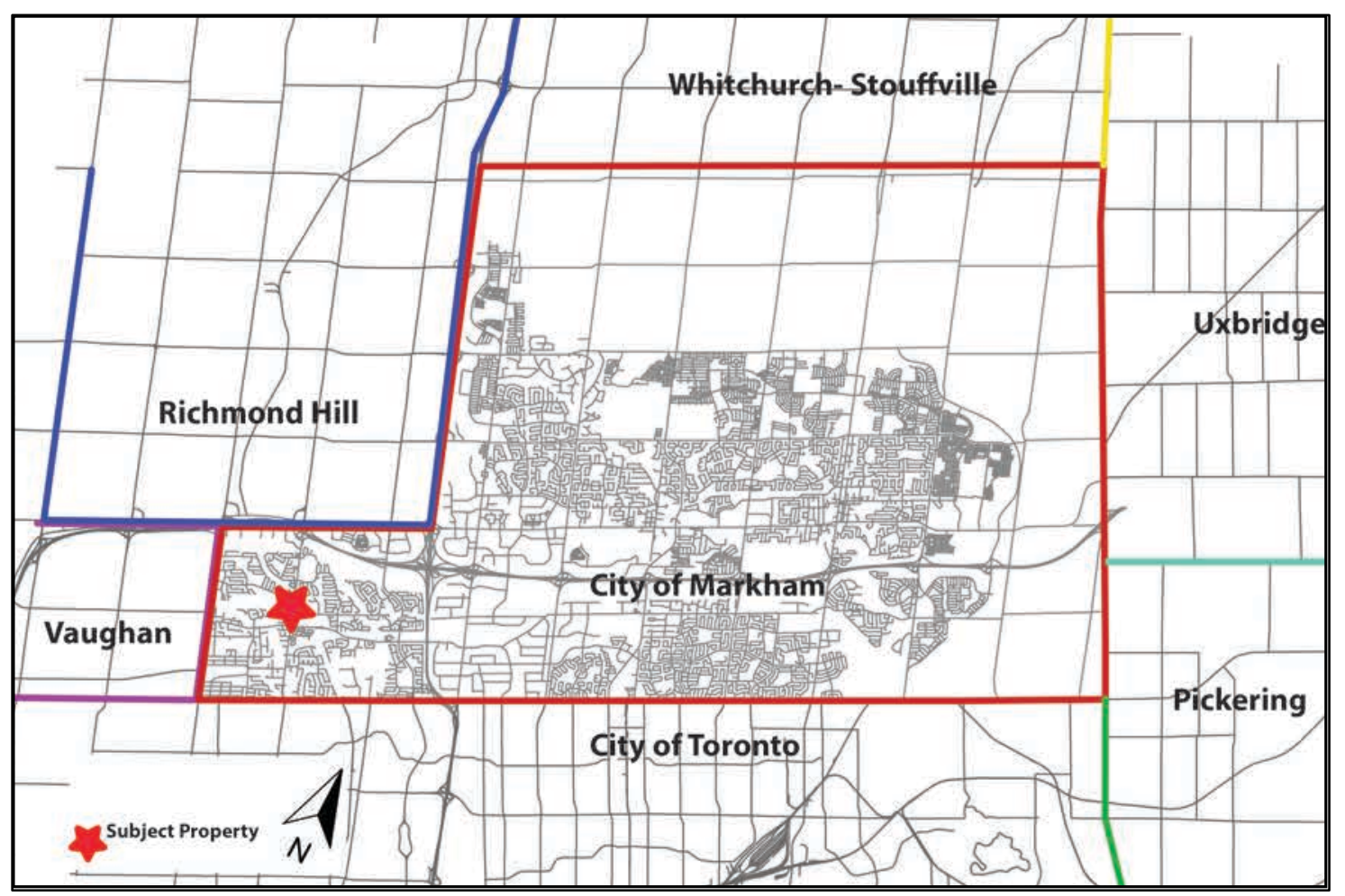

The City of Markham is unlike Toronto, due to the fact that there are large 
tracts of land still available to be developed. For most developers, their feasibility analysis or pro forma is better suited to invest in Greenfield development, as their internal rate of return remains higher than to redevelop an infill property. However, Markham has increasingly seen an influx of infill redevelopment projects along Yonge Street, which divides the City of Vaughn and the City of Markham. This is beginning to occur in recent years due to increased allowable densities outlined in the City of Markham's Official Plan; although the City's zoning by-law has yet to be updated to reflect the intensification policies. Markham is an excellent example of an emerging municipality dealing with issues of urbanization. The shift from a suburban municipality to an urbanized one is bound to have some growing pains, since many of these new policies will be met with opposition by local residents, and the implementation of suitable policies to improve the public realm, urban form, and reduce automobile use can be challenging. 


\subsection{Case Studies}

There are two case studies that were chosen in the GTA to be examined thoroughly; Olde Thornhill Village, Markham, and Humbertown Shopping Centre, Etobicoke. These case studies will provide contrasting views of past and present redevelopment proposals. It is important to gain experience of existing Greyfield barriers during the redevelopment process, such as the Humbertown Shopping Centre, which is currently undergoing a thorough planning process. In addition, there is also a need to uncover positive and negative qualities of a constructed Greyfield site; Olde Thornhill Village was completed in 2006. The combination of these case studies will provide significant insight into potential barriers of Greyfield redevelopment, a wellrounded analysis, and valuable recommendations.

\subsection{Olde Thornhill Village, Markham, Ontario}

\subsubsection{Site Context}

Markham is located north of the City of Toronto in York Region, and is the region's largest municipality with a population of 301,000 in 2011 (Statistics Canada, 2012a). A Greyfield case study that has seen a successful outcome and recently undergone redevelopment is Olde Thornhill Village in Markham. This site has been transformed from a retail mall into a revitalized commercial retail centre with a substantial residential component of stacked townhomes and apartments. Thornhill is located in the 
southwestern portion of Markham; bounded by Yonge Street and Highway 404 to the east. The area consists of single-family detached houses with many proposed and existing condominium developments along Yonge Street, Markham's most Western boundary shown in Figure 2

Figure 2: Olde Thornhill Village, Markham-Building Footprints

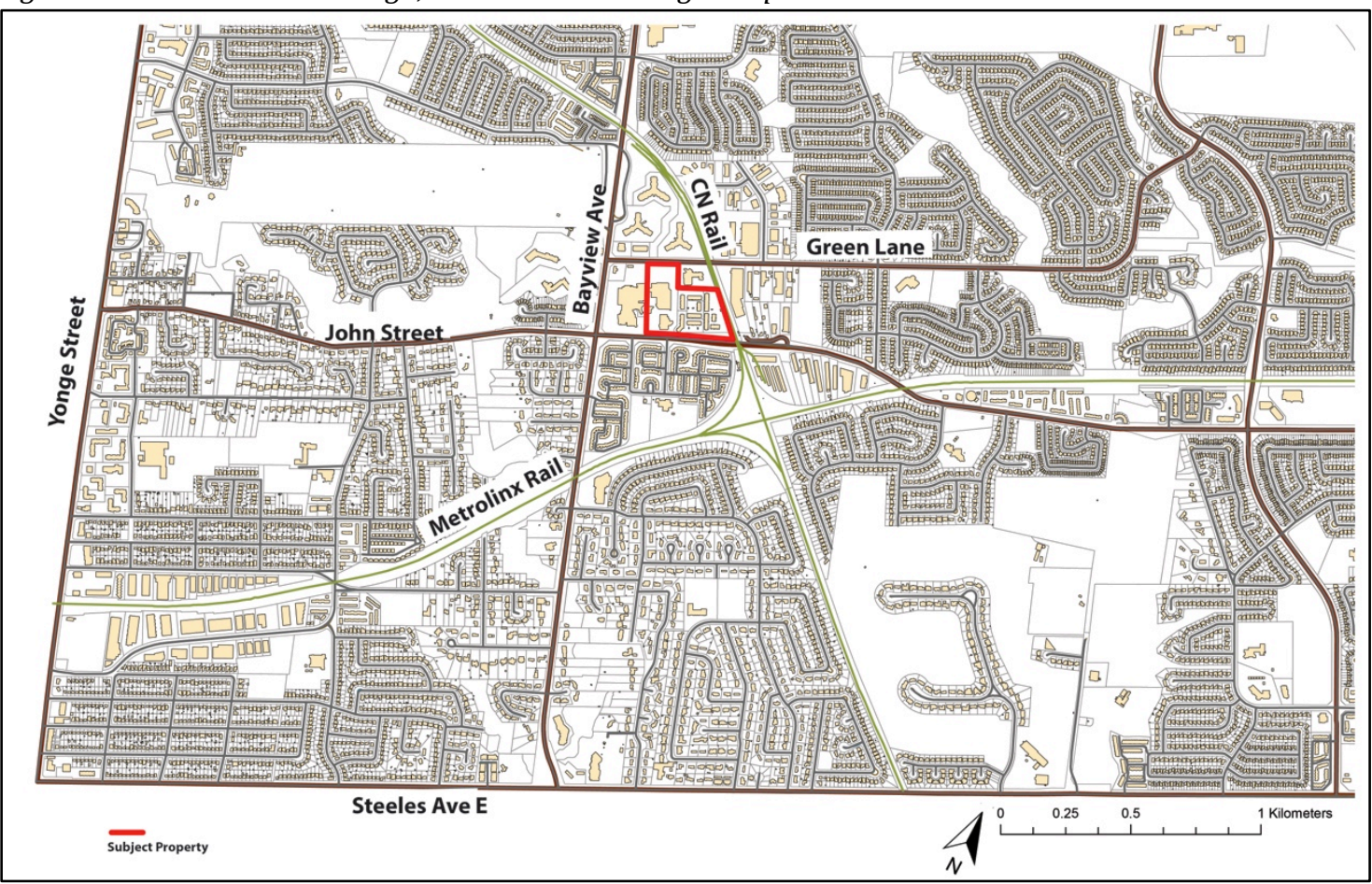

\subsubsection{Site Description}

Olde Thornhill Village can be found at the northeast corner of Bayview Avenue and John Street. The subject property is located at 300 John Street and abuts the $\mathrm{CN}$ rail line directly to the east. There is road access from both Green Lane to the north, as well as John Street to the south. There is also an institutional use, St. Luke's Catholic Church, which is located on the northeastern portion of the site and was not part of the redevelopment. The 
neighbourhood is predominantly home to single-family detached dwellings, though there are higher density units such as 2-storey condominium townhomes south of John Street, and three apartment buildings located on the north side of Green Lane with heights of 15-storeys (CMHC, 2008). These apartment buildings are the highest in the surrounding neighbourhood, which were built in the late 1970's. There are also significant portion of employment lands situated east of the subject property, between John Street and Green Lane, indicated in Figure 3 by large building footprints. An adjacent community centre is located to the west of the site; some amenities include an ice arena, fitness room, and library.

Figure 3: Olde Thornhill Village- Site Context

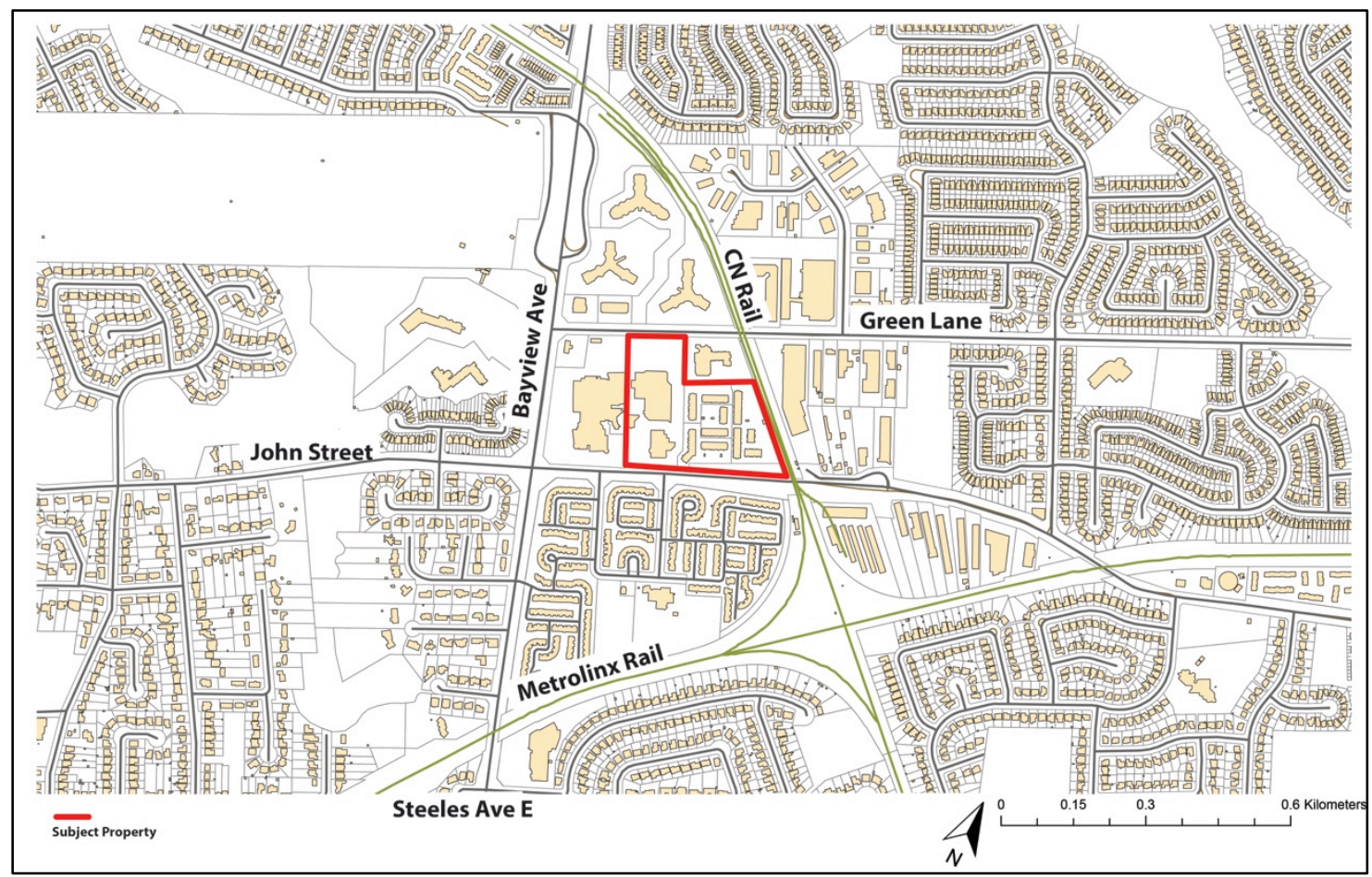


Public transit services the site on John Street and on Bayview Avenue, which is approximately a two-minute walk away. There is more frequent transit service found on Bayview Avenue, which includes both regional and GO bus service for destinations outside of Markham. The size of the site is indicated in Figure 4, and also identifies the townhomes to the south, residential apartments to the north, and industrial lands to the east.

Figure 4: Olde Thornhill Village- Figure Ground with Roads

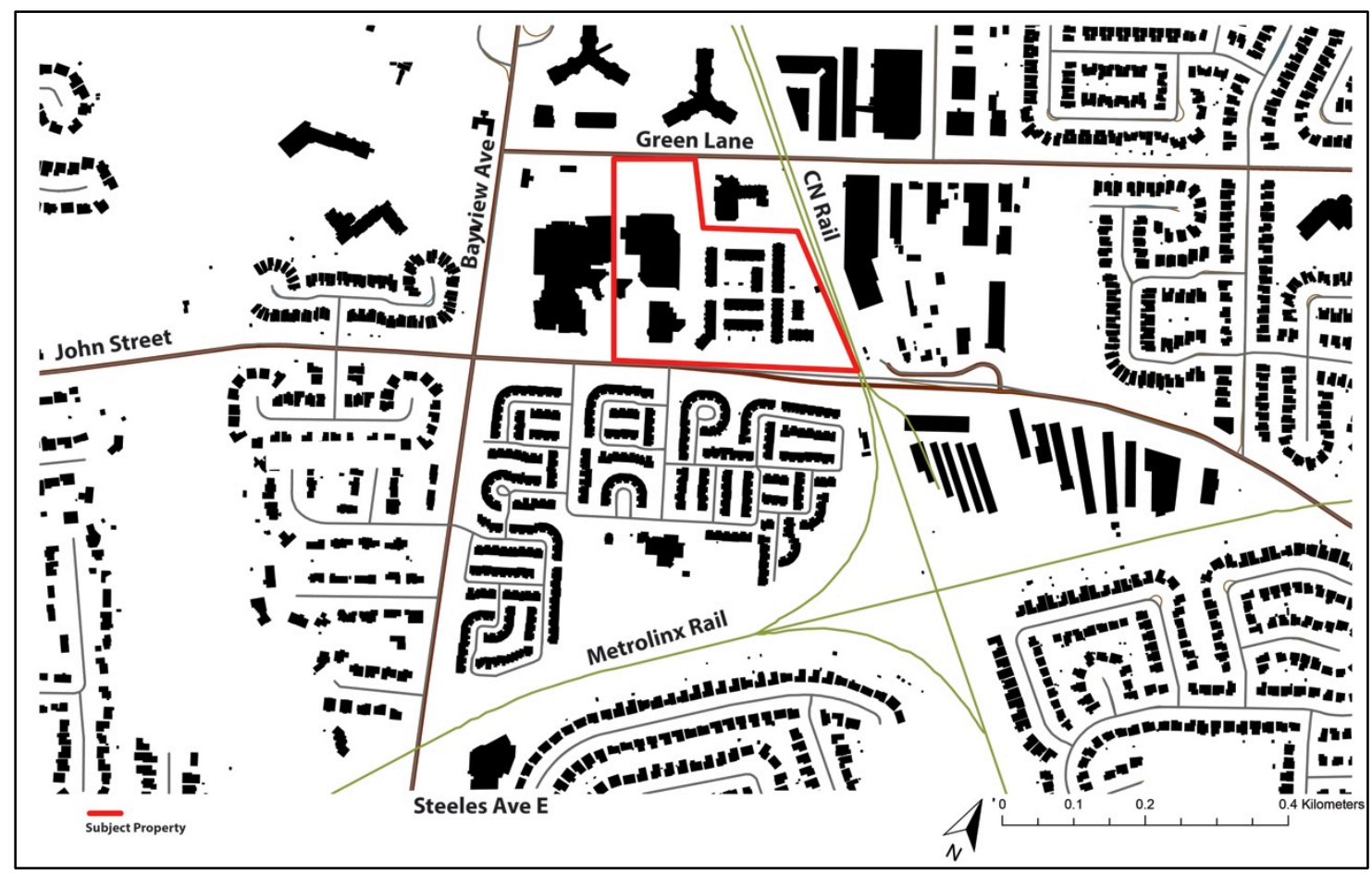




\subsubsection{Site History}

The site was once home to a 23,226 square metre shopping mall that included a Winners and Zellers as tenant anchors (CMHC, 2008). A 6-storey office building is also part of the initial development and still remains onsite, shown in Figure 5.

Figure 5: Historic Photo with Existing Office Building

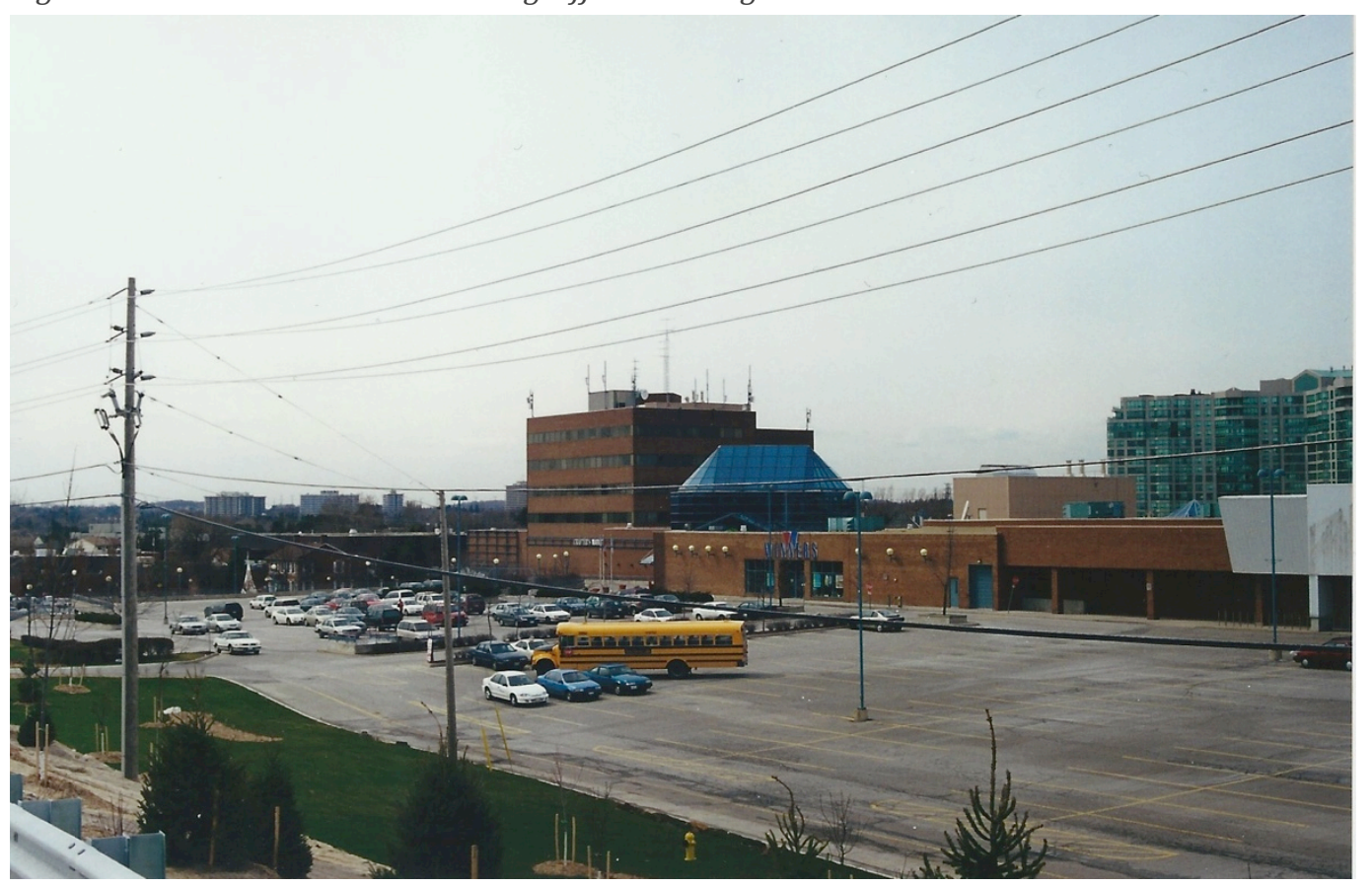

Not only did this Greyfield include a large surface parking lot but it also incorporated a structured parking lot as well. The mall was constructed in 1980 and was never successful due to its location, which lacks access to Bayview Avenue. Moreover, the interior layout presented was awkward and inconvenient. This site was a typical Greyfield before redevelopment, as shown in Figure 6. 


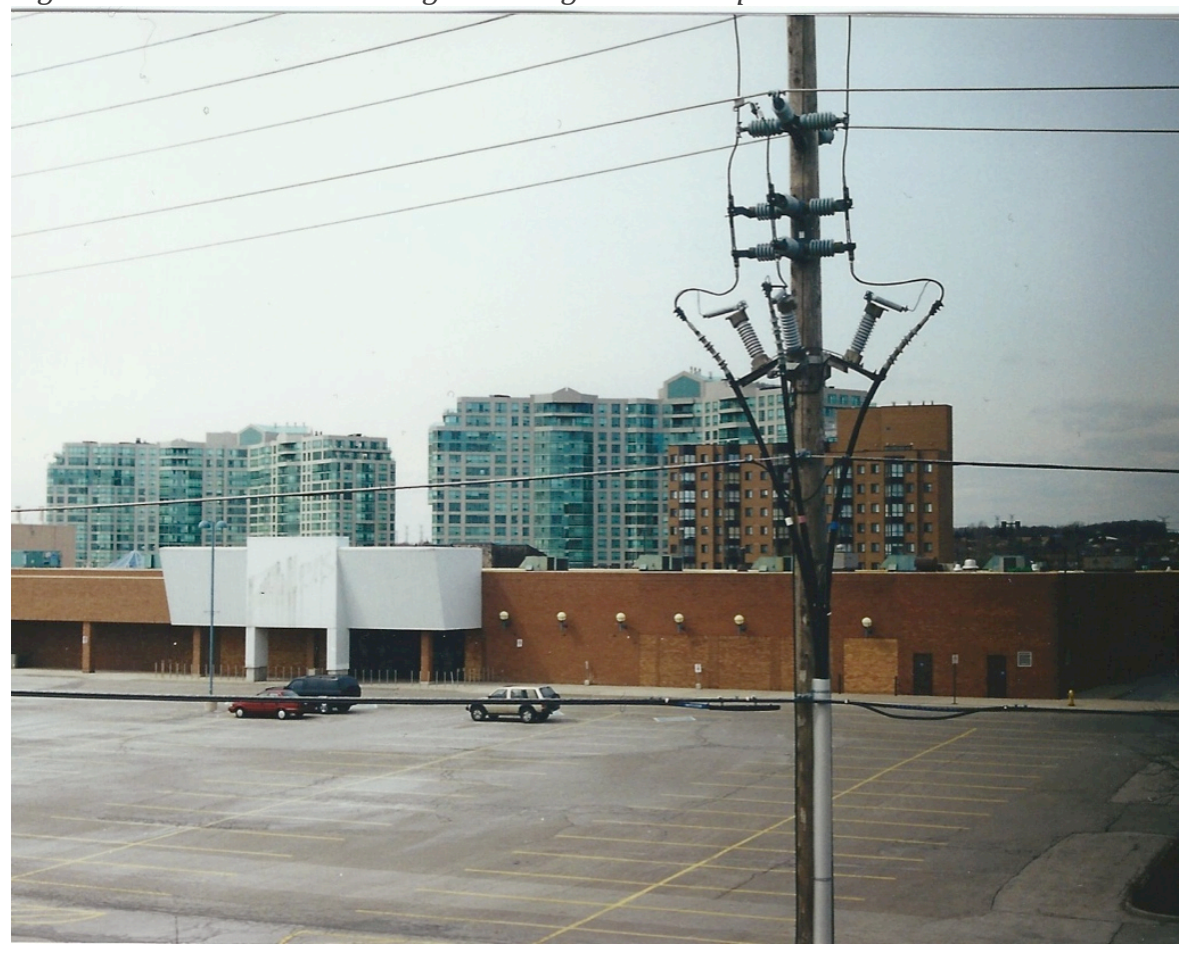

Before the mixed-use redevelopment application, which was ultimately approved and built, the Markham planning department received an application to demolish and build Big Box home improvement store. A key informant noted that City staff recommended denial of the application and was also met with opposition by the surrounding neighbourhood. The application eventually was denied by City Council as it was reported to be incompatible with the existing landuses and well-established neighbourhood. The application was appealed by the developer but was eventually denied by the Ontario Municipal Board in 2002. 


\subsubsection{Redevelopment Proposal}

The planning application for the Olde Thornhill Village redevelopment required several amendments to City policies and by-laws. A zoning amendment was necessary as the required density and mixed-use proposal was not permitted under the City's zoning by-law. A site-specific Secondary Plan amendment was also needed to ensure urban design principles guided the redevelopment. A key informant acknowledged that these principles were related to site plan design, open space, and connectivity within a mixed-use site. The City's Official Plan designated the property as Community Amenity Area, which enables medium density development with commercial and retail uses. Moreover, the Thornhill Secondary Plan supports a range of housing types and was met by the developer through a combination of condominium townhomes and apartment units. The redevelopment of the Greyfield also required site plan approval by the City of Markham.

The plan was staged in two phases. The first phase was developed by Rosebud Homes Development Corporation; a collaborative venture between Harry Kohn Architects and the Townhomes of Thornhill Village Inc.

Sundance Developments Corporation later developed the second phase. The first phase incorporated the development of the 220 units of townhomes, as well as the eastern facing façade alterations to the existing 6 -storey office building, shown on the site plan in Figure 7. 
Figure 7: Olde Thornhill Village- Phase One Site Plan

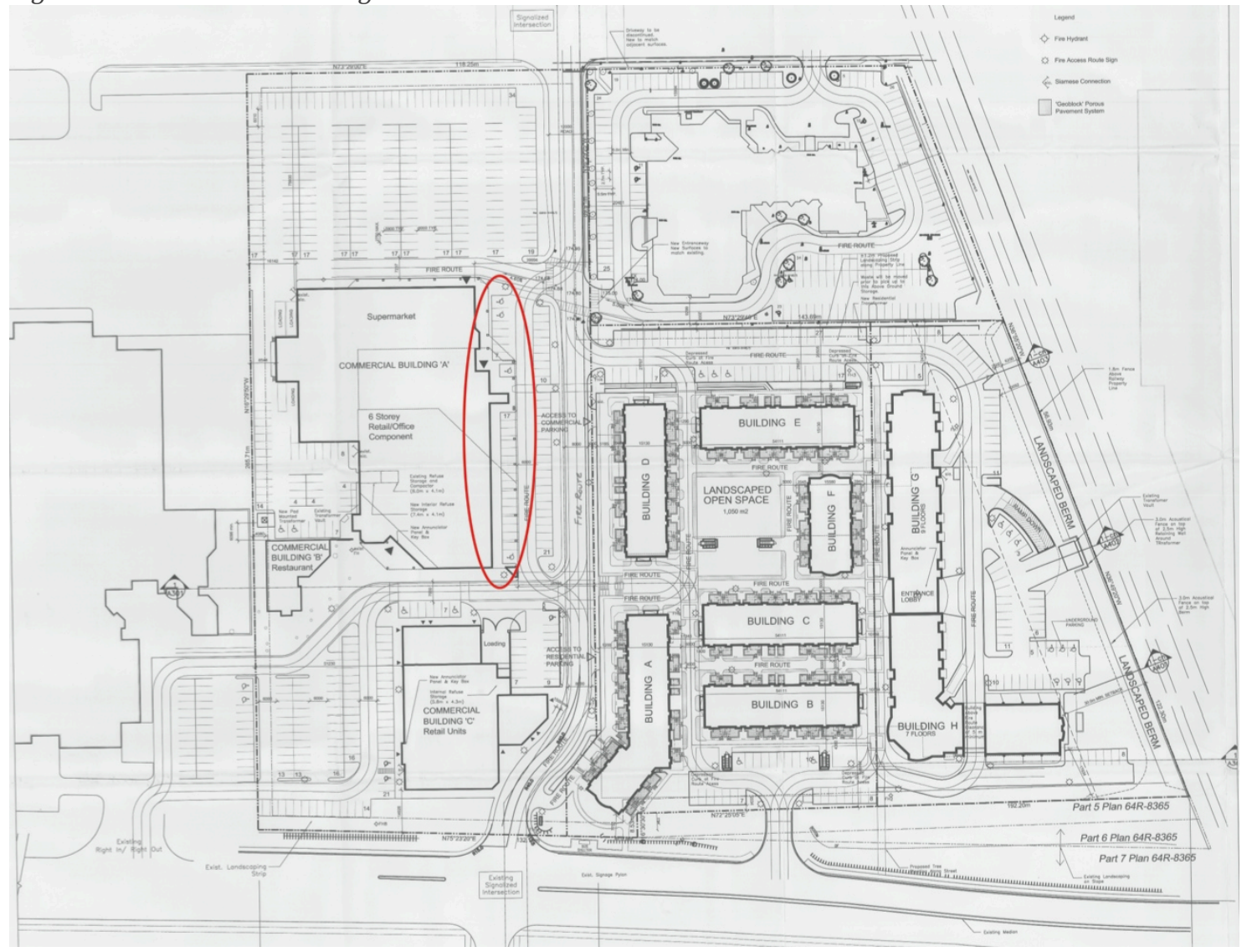

Source: Kohn Architects, Site Plan, 300 John Street, Markham

The office building was renovated and expanded to include a medium sized grocery store. The developer wanted to utilize the existing parking structure within the townhome construction. The townhomes were intended to be constructed above the existing parking garage and allow pedestrians to access the commercial retail at-grade. This site plan design enabled the residential portion of the redevelopment to be at a higher elevation to provide privacy and adequate access simultaneously (Figure 8). 


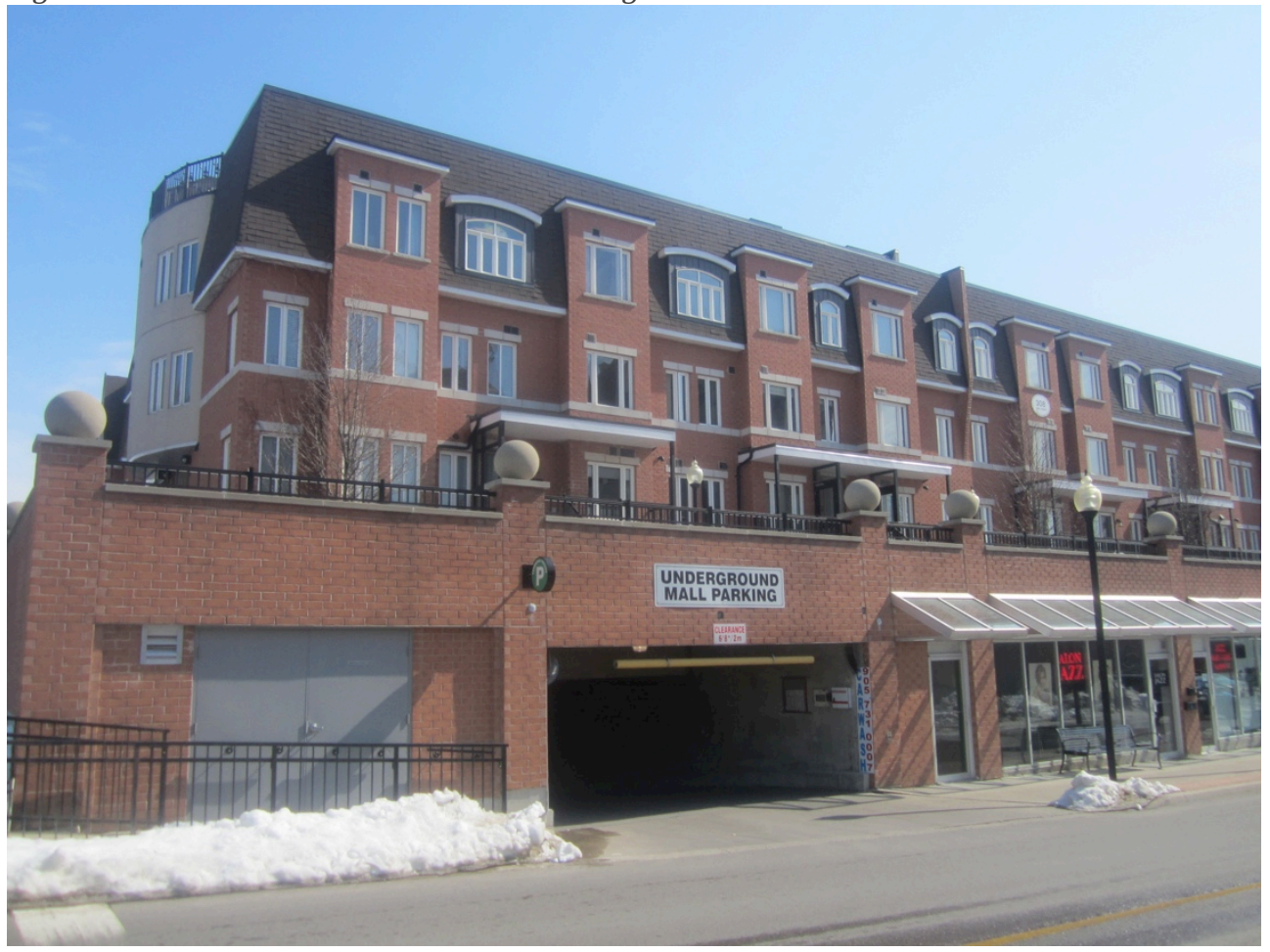

A significant design strategy implemented onsite dealt with traffic circulation and human scale ‘small town' street design. This roadway plays an important role in the site plan as it serves as a connection from John Street to Green Lane, the two main site access points. It also serves as a functioning pedestrian walkway that provides access to both the residential and commercial components onsite. A key informant stated that the design of this street was vital to the success of the commercial units, reducing automobile speed onsite, pedestrian connectivity, and improving traffic circulation. Figures 9 and 10 dictate the width of the street, the pedestrian walkway, and access to the retail units. 
Figure 9: Street Design with Pedestrian Walkway- Facing South

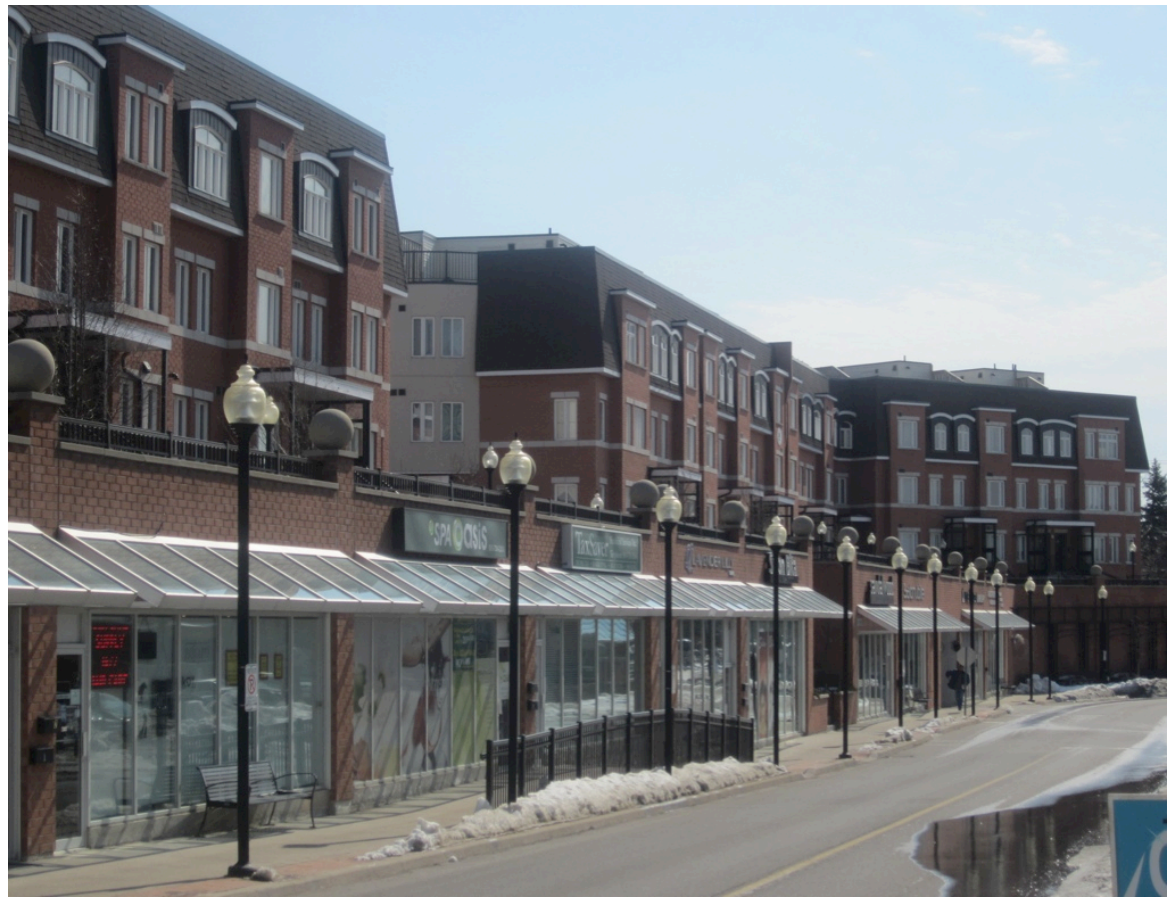

Figure 10: Entrance from John Street- Facing North

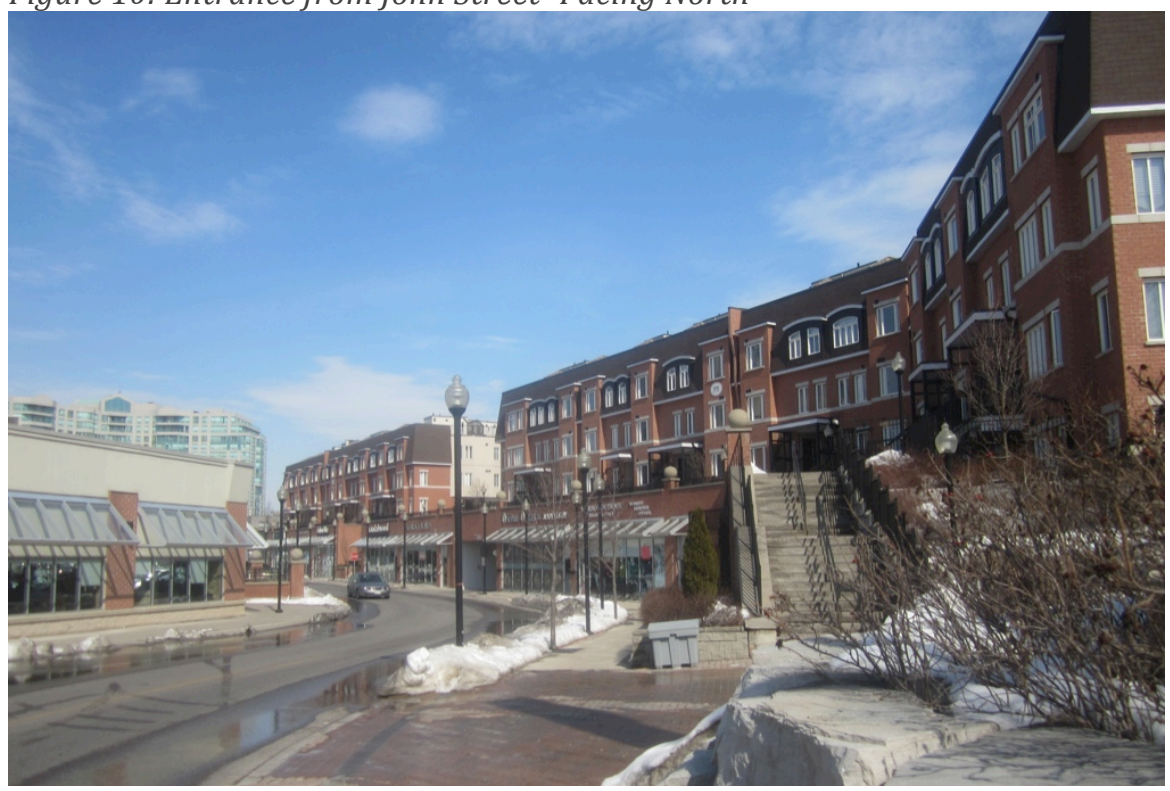

The provision of open space was provided onsite directly in the middle of the townhome complex. This small private park offers the opportunity for 
residents to enjoy the space passively through benches and a gazebo.

Children can actively use the space by taking advantage of a small playground, shown in Figure 11.

Figure 11: Private Park for Residents

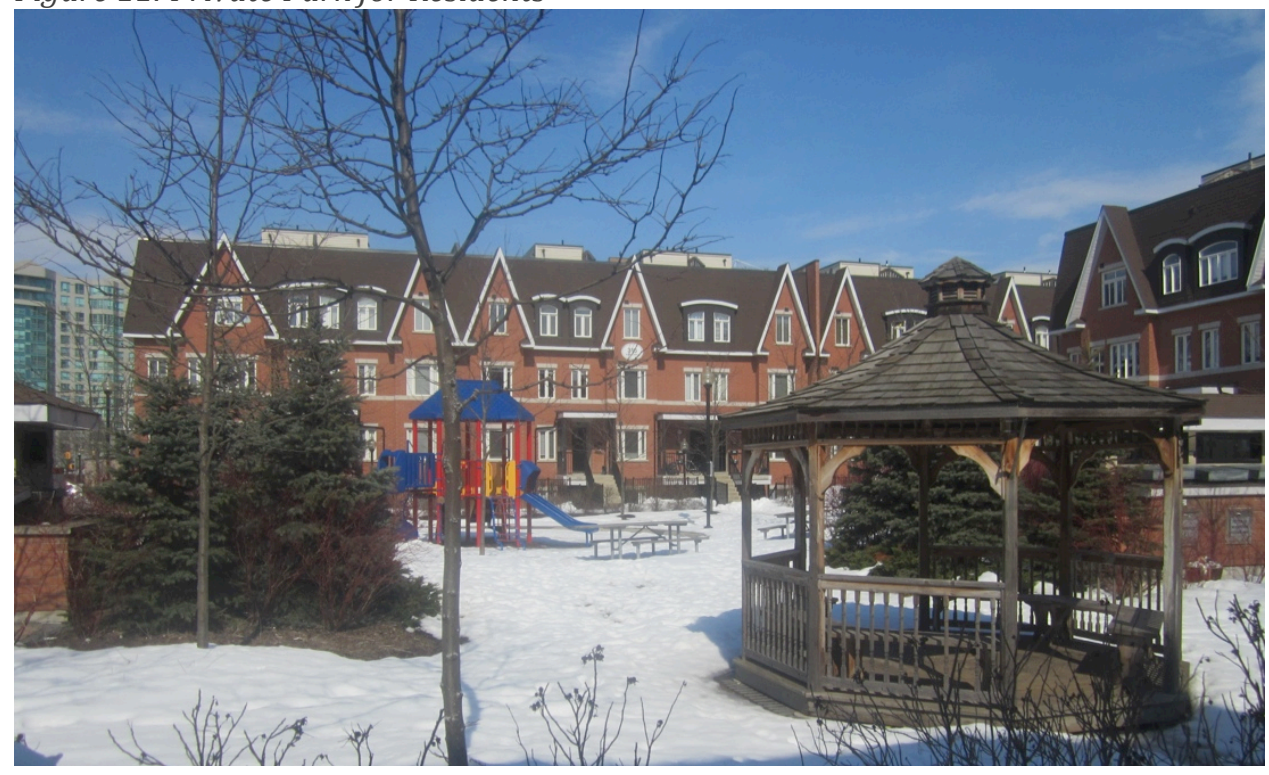

The second phase was established to construct two apartment buildings; one 9 -storeys and the other 7 -storeys, totaling 224 units. The second phase did not include apartment units as proposed, but rather townhomes. In 2008, a site plan application was submitted to construct 128 units of townhome condominiums. The cladding of these townhomes provides modern appeal that is aesthetically appealing and fit well with the original townhouse design, shown in Figure 12. 


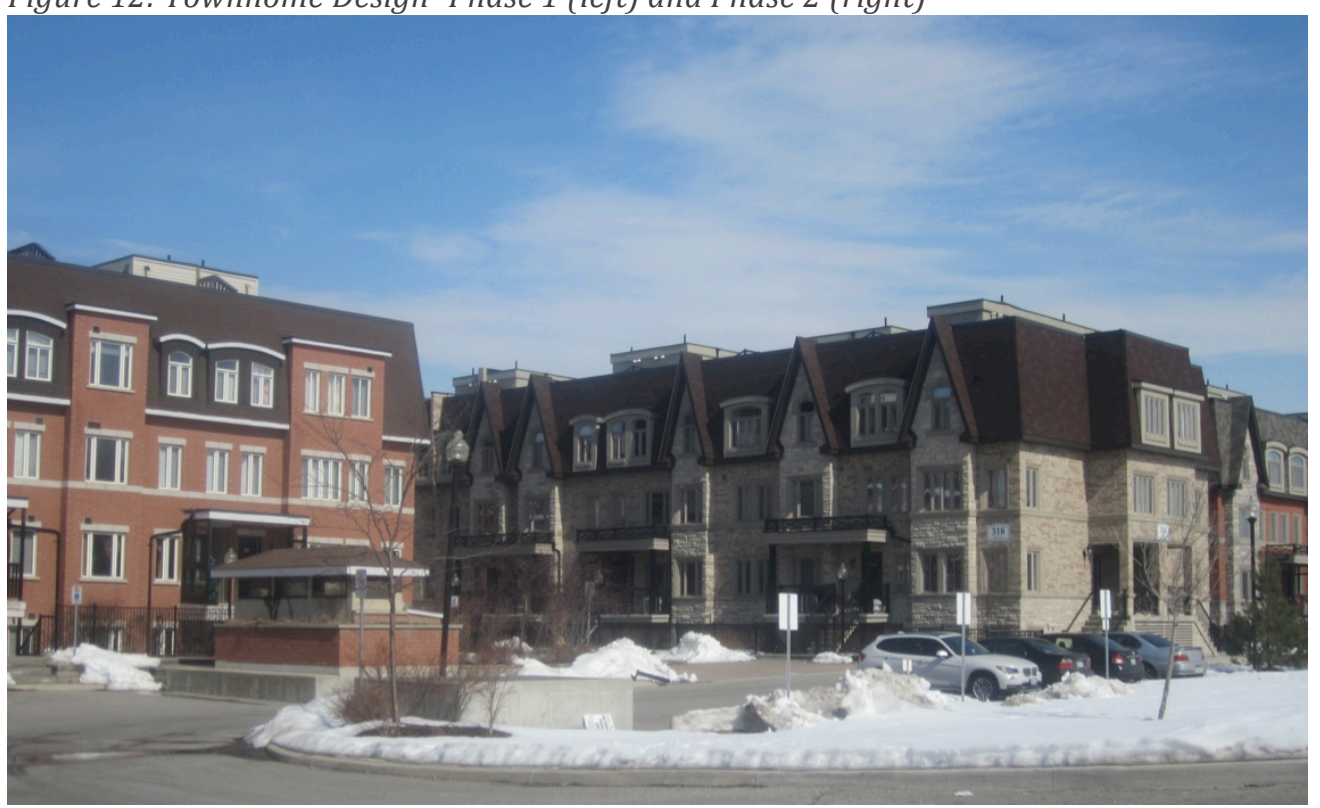

\subsubsection{Redevelopment Barriers}

There were many challenges that arise in Greyfield redevelopment, and this project was no exception. The most troubling issue involved traffic circulations and parking onsite. The design of the internal street provided the access needed while reducing automobile speeds and increasing pedestrian comfort. The internal intersection where residential traffic converges with the retail and office traffic did produce a significant problem; traffic studies were conducted in order to mitigate this problem and were ultimately resolved through the site plan control process. It is clear that this intersection does present challenges for pedestrians because of the awkward convergence of traffic entering the intersection. St. Luke's Catholic Church was concerned for pedestrian access and safety with the redevelopment proposal, especially with relation to the internal intersection that abuts the church's property. 
Other design concerns arose during the planning process such as fire route access to the townhouses. The developer was planning to keep the structured parking intact and use it as part of the redevelopment, in order to make the redevelopment economically viable as it was calculated within their feasibility analysis. The City of Markham required the developer to demolish the structure as it was not properly engineered to accommodate the weight of a standard fire truck. This led to the construction of an entirely new and reengineered partially underground parking structure. This had a major effect on the developer's bottom line, though construction still took place.

Another serious barrier that occurred during the planning process involved the appraisal value of the property, which is used to calculate the total sum of cash-in-lieu to be paid to the City for parkland dedication. Since the property is a Greyfield, which are found within well-established neighbourhoods, the cost of land is significantly higher compared to Greenfield development. The appraised value of the site was $\$ 4,476,000$ at the execution of the site plan agreement in 2005 . The calculation of the cash-in-lieu is based on the number of units, the appraised value, and the land area. The open space that is provided onsite is not discounted from the cash-in-lieu fee, as the small park is a private space. The redevelopment eventually led to the cash-in-lieu fee of $\$ 1,137,488.24$ for parkland dedication. This cost in conjunction with 
development charges of $\$ 5,950,000$ had a significant effect on the generated revenue from the redevelopment, which is a significant Greyfield redevelopment barrier.

The viability of the onsite commercial units was a concern during the planning process and remains today. The size of the commercial units does not accommodate a wide range of tenants, but mainly personal service shops such as nail salons and hair salons. This does not provide a range of tenants that offer a variety of shopping opportunities to the surrounding neighbourhoods. The location of these units on the site plan was contentious because their location plays a great deal into the success they experience. A key informant noted that it was unclear whether it was appropriate to design the internal street with storefront parking. It was ultimately decided that a pedestrian oriented design without parking served the site best. Although the commercial units are not ideal, they do contribute to the mixed-use redevelopment, which are accessed by onsite residents as well as the outside community.

\subsubsection{Summary}

Overall, the Olde Thornhill Village redevelopment has been considered a success due to the connectivity between uses, at-grade commercial retail, and the integration of new uses with the existing office component. The proposal was supported by the City of Markham during the process and was regarded 
as an appropriate redevelopment by the surrounding neighbourhood. St. Luke's Catholic Church had several concerns throughout the process concerning pedestrian connectivity to the grocery store and existing office building but compromise was reached between the church and the developer. This redevelopment would not have been as much as a success if the residential use was comprised of one or several condominium towers. City staff noted that mid-rise apartment or condominium buildings of 8-10 storeys in height might be appropriate, but would also require additional dwelling types such as townhomes.

Several barriers were involved in this redevelopment such as expensive parkland dedication cash-in-lieu fees, due to the high-appraised value within a well-established neighbourhood, coupled with significant development charges. It is clear that Greyfield redevelopment requires knowledgeable developers who understand the potential costs that are involved and to include these costs within their pro forma. Although, the unexpected need to reengineer the existing structured parking garage to accommodate fire truck access is difficult to foresee and could only be uncovered during the construction process. The City of Markham had many policies in place to guide this redevelopment such as the Thornhill Secondary Plan and the Official Plan which promoted mixed-use development and pedestrian oriented design. Mixed-use intensification and transit oriented development 
were key objectives of these policies and are considered a success. The public consultation alleviated neighbourhood concerns involving increased traffic, enhancement of a range of housing typologies in Thornhill and avoiding any major changes to the overall site plan of the project (CMHC, 2008). 


\subsection{Humbertown Shopping Centre, Etobicoke, Ontario}

\subsubsection{Site Context}

The Humbertown Shopping Centre, located in Etobicoke, is a well-

established commercial retail destination that provides a wide range of retailers including Shoppers Drugmart, Loblaws, LCBO, among others. In early 2012, the owner of the property, First Capital Realty, came forward with a redevelopment proposal and received mixed opinions on the application. There has been three different proposals that have been executed and altered based on community and City staff feedback, though no formal decision has been made to date. There has been continued backlash to the redevelopment of the shopping centre from the community association called the Humber Valley Village Residents Association (HVVRA). The proposal seeks to revitalize and increase retail, expand office space, and include several residential condominiums onsite. Etobicoke is located in the western portion of the City of Toronto and has a population of 595,000 in 2006 census data (Statistics Canada, 2007). The location of Humbertown Shopping Centre is outlined in Figure 13, and indicates the surrounding building footprints. 
Figure 13: Humbertown Shopping Centre Figure Ground

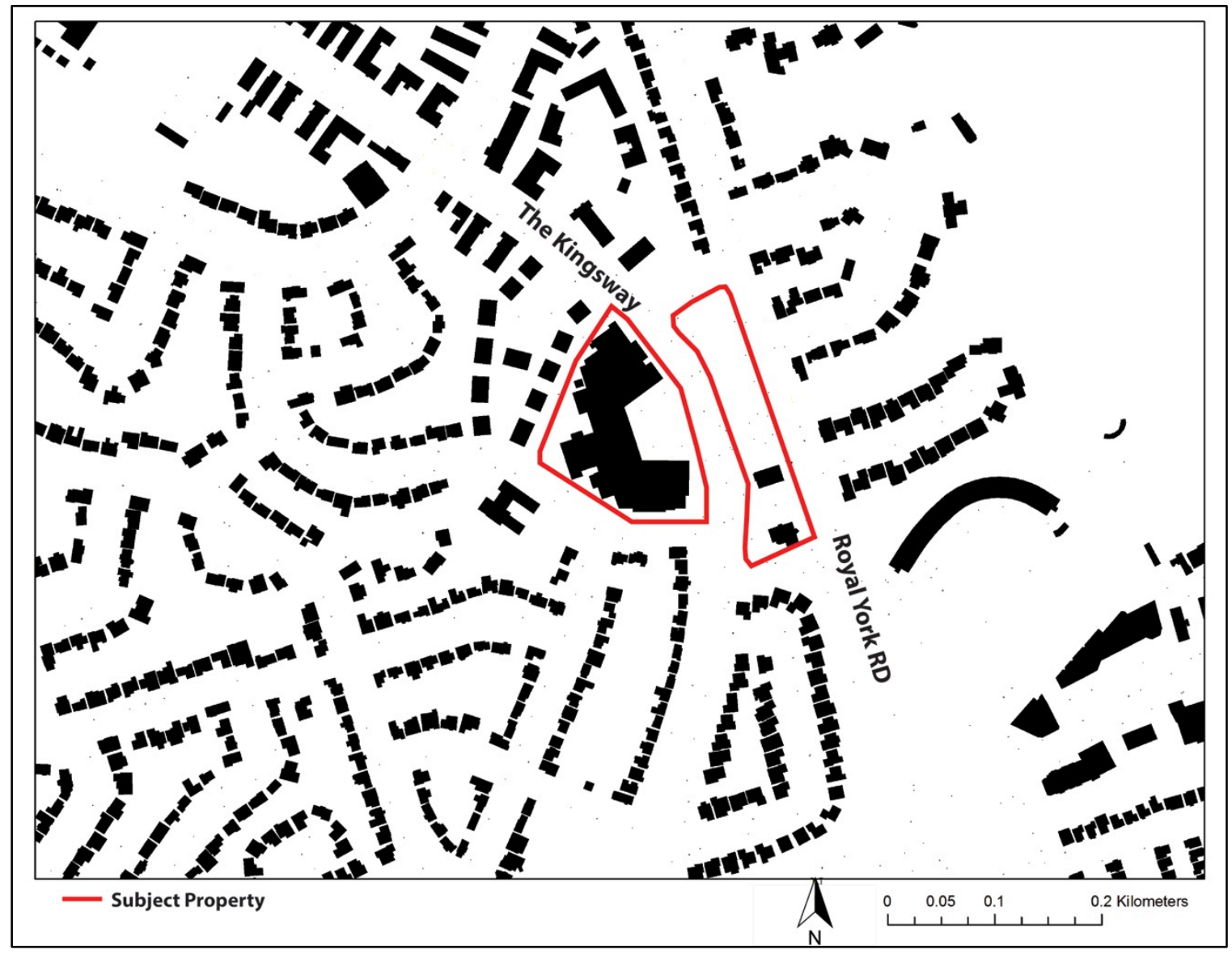

\subsubsection{Site Description}

Humbertown Shopping Centre can be found in the Humber Valley Village neighbourhood in Etobicoke, a few kilometres west of the City of Toronto proper. It's municipal addresses include 270 and 259 The Kingsway and 1144 Royal York Road, depicted in Figure 14. 


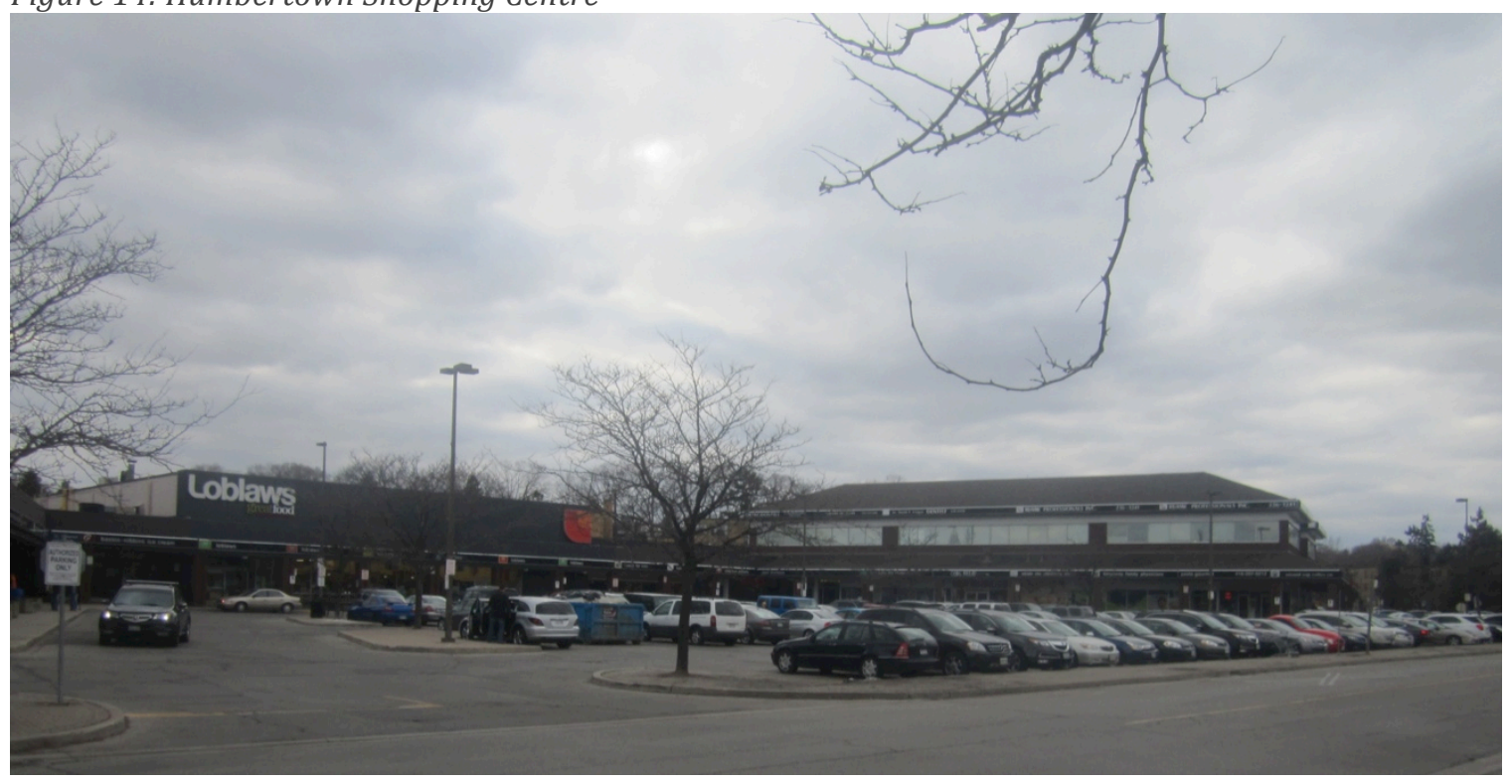

This location is easily accessible by public transit as it is approximately 1.7 $\mathrm{km}$ from the Bloor-Danforth subway line. There is frequent bus service along Royal York Road to and from the Royal York subway station with a bus stop at Dundas Street West, although, the site itself tends to be accessed by automobile users due to its suburban location. The size of the site is approximately 3.6 hectares and is one of the larger parcels of land in the neighbourhood, as indicated in Figure 15. 
Figure 15: Humbertown Shopping Centre-Surrounding Properties

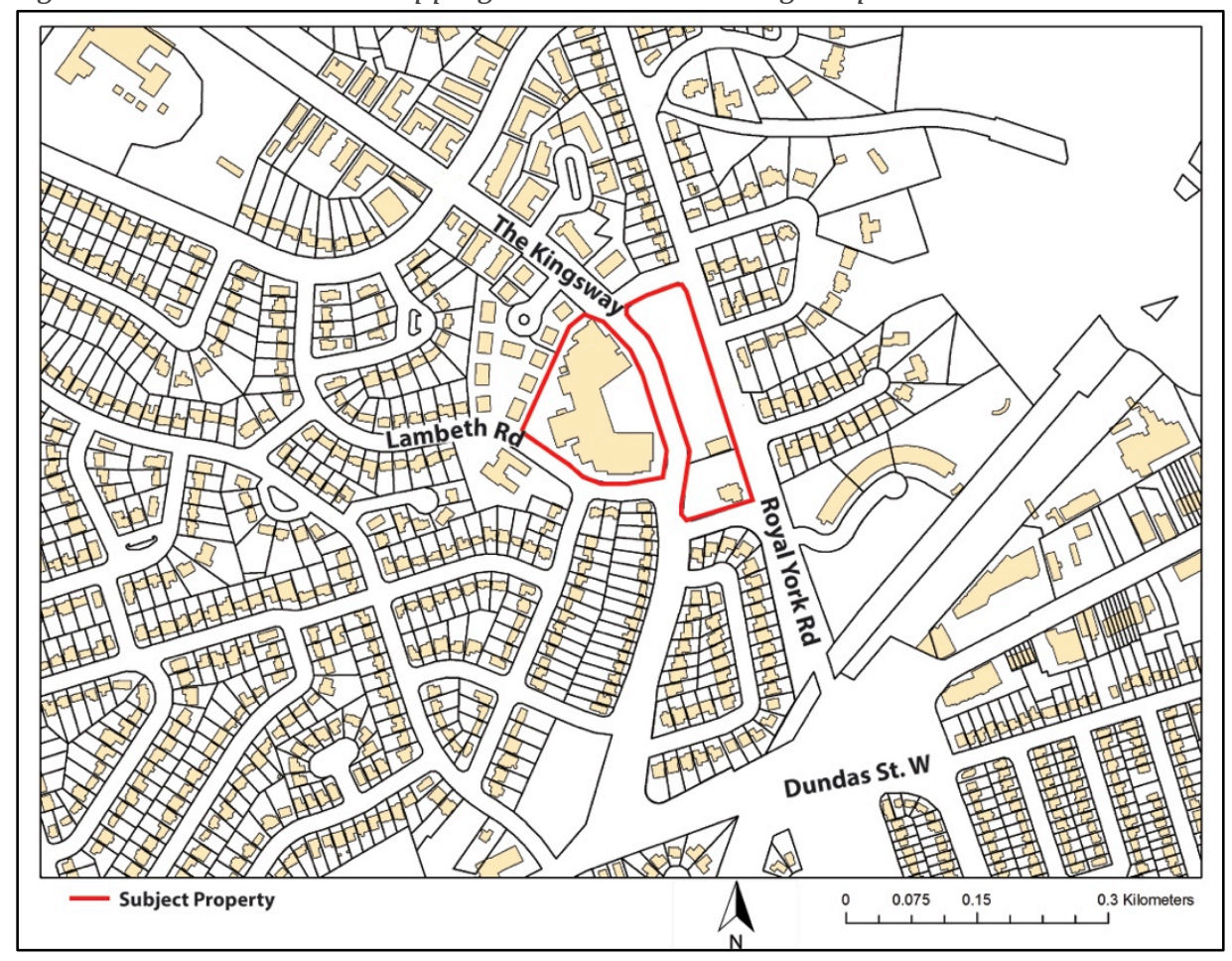

The surrounding uses are predominantly residential with some commercial uses on the southeastern side of Royal York Road. The local neighbourhood is well established with single-family detached dwellings. The largest apartment building in close proximity to the subject property is 17 -storeys, is found on the northern edge of the site and divides The Kingsway and Royal York Road (Figure 16). Immediately southwest, on Lambeth Road, is the St. Giles Presbyterian Church, which faces Humbertown Shopping Centre. 


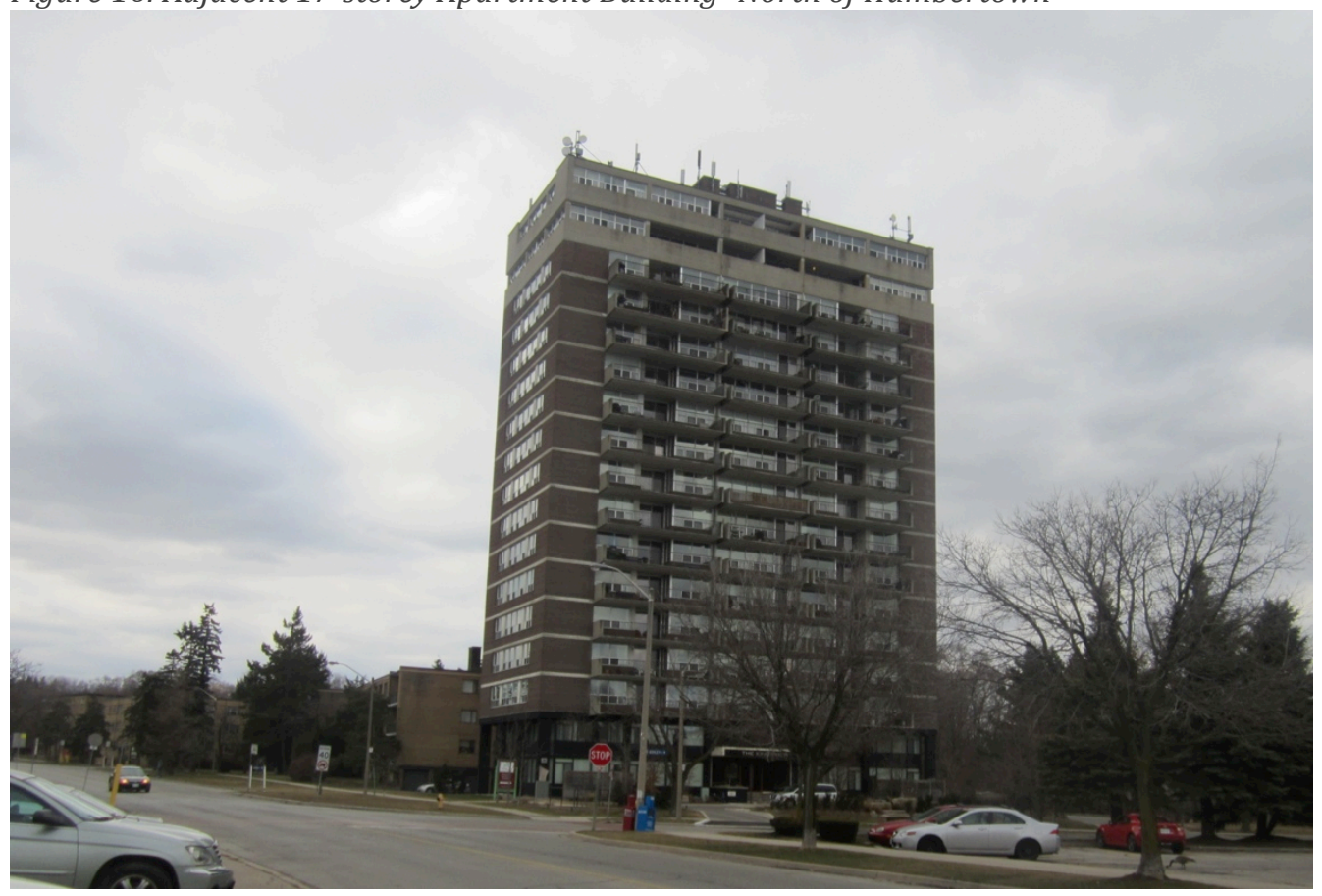

There are also several other apartments surrounding Humbertown Shopping Centre located directly to the east of the subject property, as well as along Dundas Street West. Although the area is comprised of mainly single-family detached dwellings, there are still a number of residential buildings that can be found in the neighbourhood. A recently built 14-storey condominium and 10-storey apartment building, shown in Figure 17, can be found to the east of Humbertown Shopping Centre. Additionally, there are a number of small apartment buildings to the northwest of 4-storeys in height. 


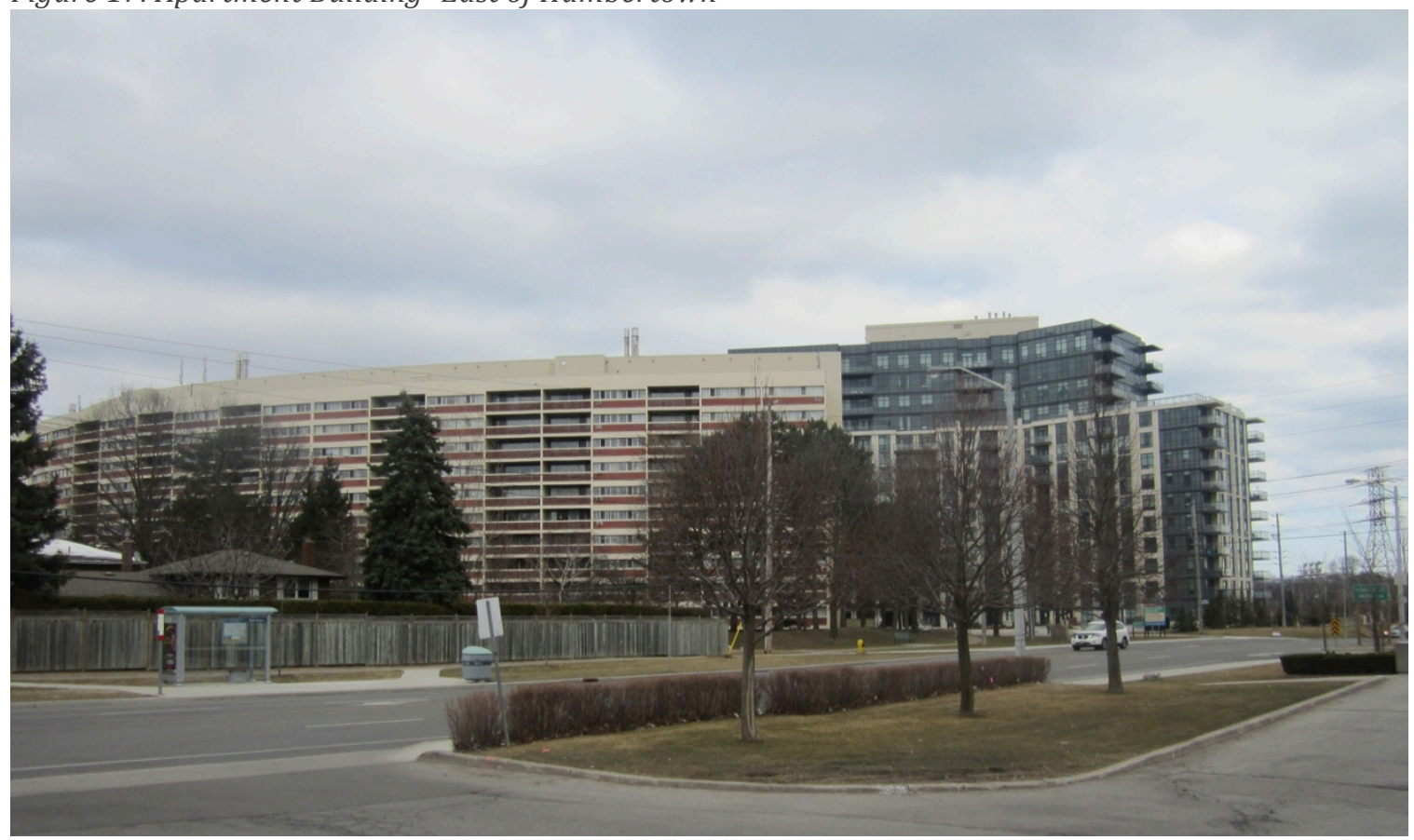

\subsubsection{Site History}

The site's current use is neighbourhood retail, which includes a Loblaws, LCBO, Shoppers Drug Mart, several banks, a few clothiers, and other small stores. The shopping centre has served the local communities for many years as it was built in the early 1950's. Currently the total Gross Floor Area of the shopping centre contains $11,150 \mathrm{~m}^{2}$ of commercial retail and $1,395 \mathrm{~m}^{2}$ of commercial office use. The largest portion of the site consists of surface parking, which once was the norm of neighbourhood retail at the time of construction. The north building is the highest structure onsite as it stands 2storeys and contains the commercial office component with at-grade retail; as depicted in Figure 18. 


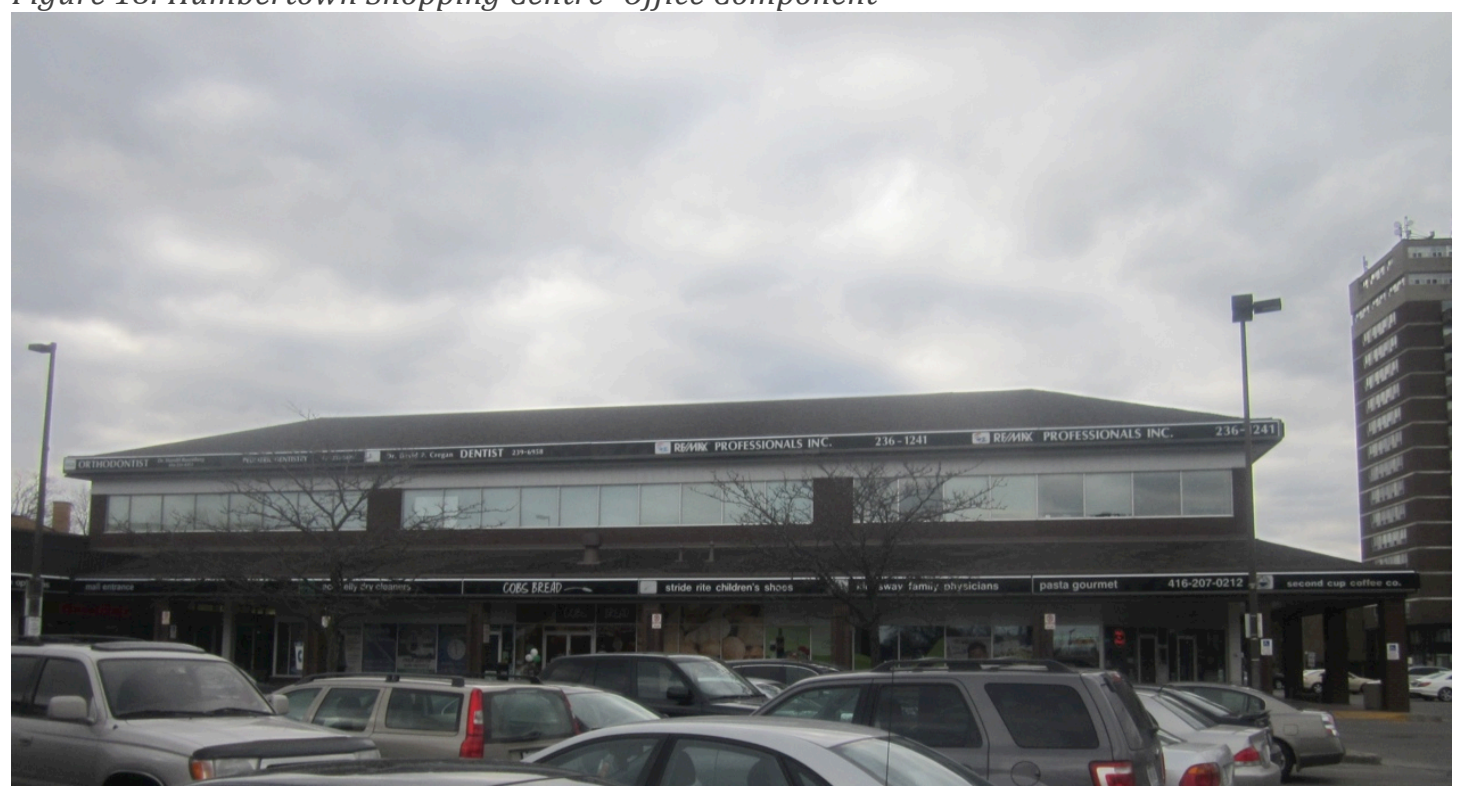

The rest of the structure remains single storey. This main plaza of the site is accessed on the west side of The Kingsway at two locations. The eastern portion of the site is devoted to surface parking and a stand-alone single storey LCBO, shown in Figure 19.

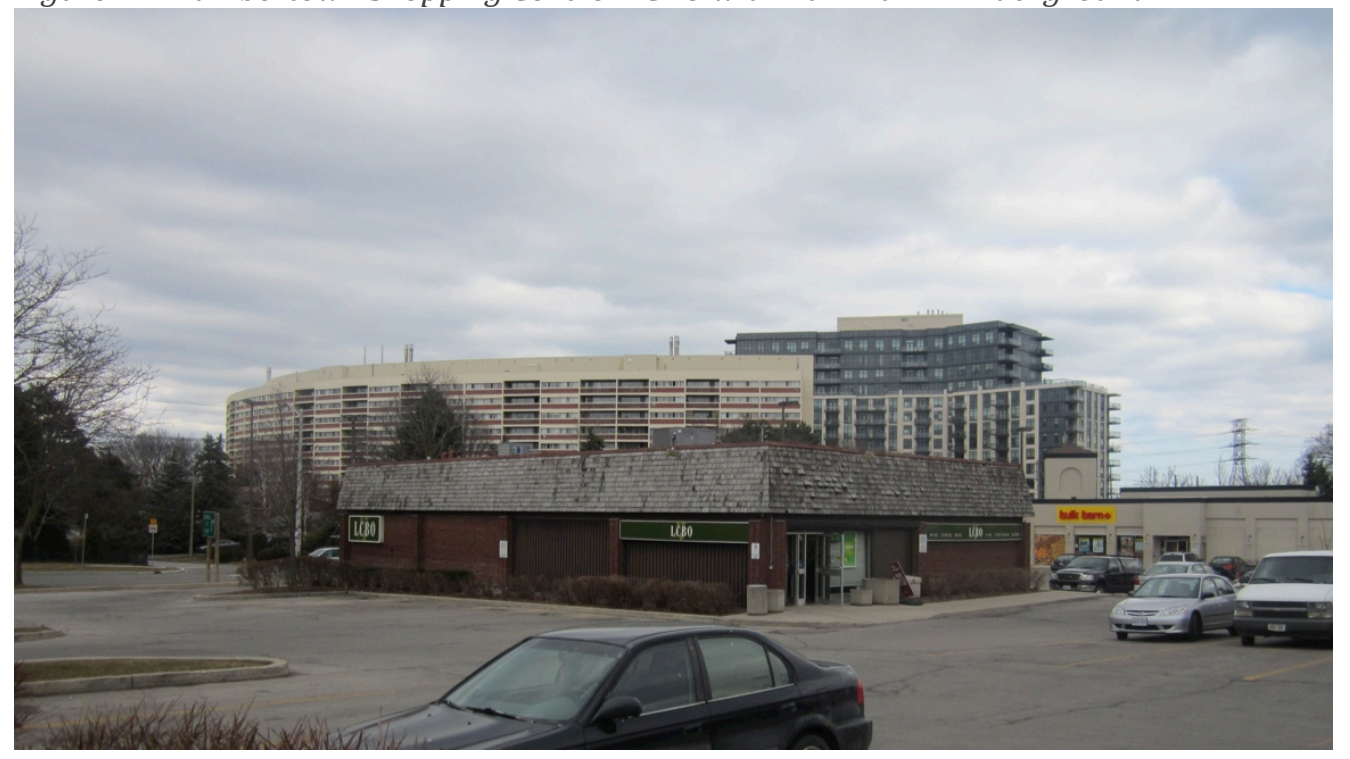


To the south, a second single storey building stands which now comprises a Bulk Barn. This lot also provides surface parking and road access from Royal York Road.

\subsubsection{Redevelopment Proposal}

Humbertown Shopping Centre is owned and operated by First Capital Realty since 2006. In 2010, they hosted a design competition in collaboration with the University of Waterloo Architecture School to present redevelopment opportunities and to display the possibilities of the site visually. This led to the formation of a collaborative team between Urban Strategies and Levitt Goodman Architects, who were ultimately chosen as the winner. These two firms joined with other experts such as Scott Torrance Landscape Architect Inc., as well as Kirkor Architects and Tridel as the residential expertise component.

The redevelopment of Humbertown Shopping Centre will require a zoning amendment because currently the as-of-right zoning does not permit residential uses. However, the location of Humbertown has been designated in the City of Toronto's Official Plan as a Mixed-use Area. This specifies that First Capital Realty is not required to amend the Official Plan or any subsequent Secondary Plan. Before the initial proposal brought forward, many informal meetings were held between executives of the Humber Valley Village Residents Association. Since January 24, 2012, there have been three 
separate planning proposals which have been repeatedly updated according to community feedback. The initial proposal was based upon preliminary feedback by the local councilor, Gloria Lindsay-Luby. A non-statutory working group meeting with the Humber Valley Village Residents Association led this proposal. The following will introduce each proposal.

\section{January 2012 Proposal}

The first proposal that was presented to the community came with a variety of concerns due to the initial height of the development and introduction of residential units. This redevelopment seeks to implement a mixed-use community that incorporates commercial-office, commercial-retail, open space and residential uses. This proposal includes a total of five buildings with heights ranging from 11 storeys to 21 storeys and comprises 682 total residential units with 28 townhouse units. This proposal had a Gross Floor Area of $81,640 \mathrm{~m}^{2}$ and $21,837 \mathrm{~m}^{2}$ of commercial space. The Floor Space Index (FSI), which is defined as the "gross floor area of all buildings on a lot divided by the lot area," was 2.24 for this redevelopment proposal (City of Toronto, 2010). Parking onsite will be accommodated through two underground parking levels to include 1348 spaces that span the entire floor plate of the redevelopment. In addition, there are 66 at-grade parking spaces available on site with supplementary on street parking. The formal application for this redevelopment was submitted on January 24 to the City of Toronto, though a formal public consultation meeting did not occur until May 2012. 
Another major aspect of the first proposal as well as subsequent proposals was the importance of open space. It is important to highlight the open space features in the redevelopment because there were several reiterations to the types and size of open spaces in each proposal. There are numerous designated open spaces for specific activities such as Lambeth Community Green, which is located on the foremost western portion of the site. This destination promotes a variety of uses such as lawn games, picnics and socializing due to its generous space. The Humbertown Court, located in the centre of the site, is another destination but caters to social events and community activities as its role is that of a market square. The trademark community space is the Humberline, which provides a link to the site's pedestrian spaces. The Humberline stretches from Royal York Road to Humbertown Court and Lambeth Community Green via a pedestrian bridge over The Kingsway. This multi-level pedestrian space offers beautiful sightlines, natural vegetation, and passive seating areas.

\section{September 2012 Proposal}

Many changes occurred from the first proposal during the summer months, as working group meetings were conducted with representatives of the neighbourhood and residents group. Five meetings were held over the summer months in order to discuss specific issues and brainstorm solutions. These working group meetings led to subsequent proposals, as the applicant's collaborative team was able to adjust the site plan to accommodate the residents' feedback. Alterations for this redevelopment proposal include the 
increase of accessible open space, reconfiguration of residential units, and height reduction of several buildings. The most drastic change to the site plan includes a substantial increase of open space onsite, from $2,336 \mathrm{~m}^{2}$ to $5,657 \mathrm{~m}^{2}$. This dramatic increase was based on the residents' feedback to include a variety of quality passive and active spaces. The Humbertown Court has now been transformed in this proposal to alter a large portion of the open space to accommodate short-term parking opportunities, now named Village Square. The square has converted from a permanent public space to a multi-use space that has the possibility for community events through scheduling.

Other alterations to this proposal include increased building setbacks away from neighbourhood frontage, as citizens as well as City staff brought concerns of shadowing and overpowering building heights forward. The final alteration to the proposal provides opportunities to accommodate senior housing within the development by converting 146 residential units with improved ground level access.

\section{December 2012 Proposal}

The most recent proposal has shifted the site plan configuration significantly, as this proposal was based upon the public consultation meetings on September $11^{\text {th }}$ and October $16^{\text {th }}$. The reconfiguration of the residential towers was in large part based on citizen feedback, as only three of the towers are residential with the highest at 12 -storeys. The remainder of the towers has been shrunk in height, with larger floor plates to be able to accommodate 
the same number of residential units. These mid-rise buildings are now better suited to the Avenues and Mid-Rise Building Guidelines but still does not meet the specified height requirement based on the 1:1 ratio in relation to the right-of-way, a concern that was mentioned by City staff. Although, Royal York Road and The Kingsway are not designated as avenues in the City of Toronto's Official Plan or Avenues and Mid-rise Building study. The number of at-grade parking stalls was reduced to 42 but 210 additional parking spaces has been added since the original proposal. Moreover, on street parking has increased considerably throughout the proposal process, based on the response from the public to include more convenience parking.

Citizens in the public meetings had a growing concern for tree preservation, requesting for tree relocation and more mature tree plantings throughout the new site plan. Similar to the September proposal, there has been an increase of building setback from Lambeth Road and Ashley Road, which is located directly north of the site. St. Giles Presbyterian Church along Lambeth Road, as well as other residential homes, has raised concerns regarding traffic circulations relating to servicing access to the site. This led to the elimination of site servicing from Lambeth Road, which will subsequently be diverted onto a private service laneway located on the northern side of the site. This area will be dedicated to service deliveries for all tenants onsite; it will be 
located at-grade with Lambeth Community Green built above. The

redevelopment proposals have been summarized in the following table.

Table 1: Humbertown Redevelopment Proposal Summary



Source: Urban Strategies Inc., January 2012 


\subsubsection{Redevelopment Barriers}

There has been a variety of concerns raised by the Humber Valley Village Residents Association, City staff, and the local neighbourhood involving the Greyfield redevelopment of Humbertown Shopping Centre. Although many of these barriers may not be prevalent until planning approval or construction occurs, some notable issues can be indicated through the initial proposals. The most important redevelopment issues presented by the residents association and the neighbourhood involve traffic circulation, parking, height, massing, scale of redevelopment, and the potential end users of the residential units. Some of these issues can be characterized with any infill development, although all of these concerns can be attributed to the overall scale of the development, leading to increased complexity. In addition, key informants identified that it may have been beneficial if a Secondary Plan was in place, in order to guide the redevelopment and ensure urban design, traffic circulation, and pedestrian oriented design are site-specific policies. This would provide First Capital Realty and the local residents expectations onsite, as detailed provisions would direct redevelopment with no need for interpretation.

A redevelopment barrier that has clearly evolved during this redevelopment is the length of the planning process, which can have a large effect on the financial wellbeing of the developer. There are countless studies that need to 
be conducted, some mandatory by the City and others are produced to provide the neighbourhood with piece of mind. There are also architectural drawings, arborist reports, and mechanical drawings that are produced for each proposal by a large team of experts, which is an added cost to the developer. Large developers are more able to absorb these costs, such as First Capital, compared to smaller firms because they are leaders in the real estate sector. However, these studies and drawings are an important aspect to any development; they also take an extended time to produce. The Humber Valley Village Residents Association has strong support from the local community that has consistently challenged the redevelopment of Humbertown. A wellestablished neighbourhood such as Humber Valley can have a dramatic effect on the approval process of the redevelopment; this should not be perceived as a Greyfield barrier because all developments need to have a thorough public consultation to include all members of the surrounding neighbourhood. A potential barrier that may arise through this process at Humbertown is the significant decrease in Gross Floor Area, residential units or commercial space. These reductions may have an adverse effect on the overall profitability of the redevelopment and lead to feasibility constraints. This could lead First Capital Realty to begin to reduce construction expenses by choosing materials that will lower cost and offer limited quality. 
The extent of the cost of parkland dedication through cash-in-lieu, Section 37 improvements, and development charges has yet to be determined. These additional costs would have been identified through the pro forma analysis of First Capital Realty's team but costs may occur that were unintended. A key informant stated that several parkland and open space studies were conducted by a third party consultant during the planning process, which indicated that the final proposal exceeded open space requirements in the City of Toronto. There was no intent for First Capital Realty to convey any open space to the City, but the excessive onsite open space may result in additional deductions to parkland dedication cash-in-lieu charges.

\subsubsection{Summary}

First Capital Realty is unlike other developers in Canada because they are committed to the long-term success of the redevelopment, as they become the property managers following construction. Most developers in Canada will strictly develop sites for the sole purpose of profiting and will sell the entire property after construction. The Humbertown proposal has been changed and approved upon based on City and neighbourhood concerns. Overall, it is fair to state that the appropriateness of the redevelopment has improved over time with substantial design efforts to establish seamless connections between retail, office, and residential uses. This is one of the most important aspects to a mixed-use community because it provides a walkable community for all users, increases commercial viability, and expands overall 
functionality. The approval process has yet to be determined, so it is difficult to understand all barriers associated to the redevelopment. The Humbertown approval process continues as the City's planning department is expected to complete a planning report on the development in April 2013. It will then be voted on by Etobicoke York Community Council based on planning staff's recommendations on May 14, 2013 and finally Toronto City Council of June 11, 2013.

The strength of the Humber Valley Village Residents Association has proven that the community is willing to challenge the redevelopment of their neighbourhood mall. They feel that their neighbourhood is a suburban environment and increased densities are not appropriate for the community. The residents association acknowledges the intensification policies in provincial legislation, but identifies the Humbertown as an unsuitable site because of its distance from Royal York subway station, suburban location, and lack of public transit options. A key informant stated that intensification is not necessary at Humbertown because the City of Toronto has met their respective $40 \%$ intensification infill growth for the year as well as 6 years in the future, due to substantial development growth in the City of Toronto in recent years. Furthermore, the residents association has produced a counter proposal that includes five buildings of 6 -storeys. Other adjustments to the First Capital Realty proposal include additional building setbacks, façade 
cascading and a neighbourhood square with water feature. The maximum height of these buildings conforms to the Avenues and Mid-Rise Building Guidelines, which is based upon a 1:1 ratio of the width of the street right-ofway and the height of the adjacent building. The success of the counter proposal for the Humbertown redevelopment was not yet determined at the time of writing.

The Humbertown Shopping Centre redevelopment proposal has been altered and scaled down considerably through the planning process. The local neighbourhood has accepted the suitability of the mixed-use component, although the real concerns involve the massing, scale and height of the redevelopment. Based on provincial policies, and City of Toronto Official Plan; the Humbertown redevelopment is appropriate based on various intensification policies. Though it does not conform to the Avenues and MidRise Building Guidelines entirely, as the height of several buildings exceed the mid-rise recommendations. The residents association has also argued that the redevelopment does not fit into the character of the neighbourhood, as low-rise single-family detached dwellings surround the site. It is clear that the Greyfield redevelopment of Humbertown will set a precedent within the area in relation to height and mixed-use development because there are many outdated and underutilized retail plazas in the region. 


\subsection{Analysis}

The case studies highlight a variety of barriers and progressive strategies that deal with Greyfield redevelopment. Both of these case studies illustrate barriers that exist during the planning process and post development, which provides a well-rounded analysis. As previously mentioned in Greyfield literature, it is important to have complete control of the site through sole proprietorship in order to ensure that a comprehensive plan can be implemented. Coordinating the redevelopment of a Greyfield with multiple proponents would be increasingly difficult in a mixed-use redevelopment and will most likely result in poor design and weak functionality. Without sole proprietorship, the redevelopment will also be disjointed with weak connectivity between uses because a comprehensive plan for the site is difficult to achieve with numerous interests of multiple stakeholders.

Several similarities were identified in the case studies as potential barriers to redevelopment that can be found in existing literature. There is a need for each municipality to identify Greyfield sites that exist within their urban boundaries and implement policy to guide redevelopment (McKay, 2006). Without guiding policies in place, the redevelopment of Greyfields will be unsuccessful with poor connectivity, traffic circulation, and lackluster design. Another major component of implementing a Greyfield mixed-use redevelopment model is the need to create real public space and human scale 
design (Sobel, 2002). Without pedestrian oriented design with strong connections to public transit, the redevelopment will struggle to maintain their commercial tenants, as pedestrian activity will be minimal. As Greyfields in Ontario are unlike sites in America, the barriers that exist in the GTA are subsequently different as well.

Mixed-use communities are more complex than single use developments, this signifies that multiple disciplinary, or sector expertise is necessary to ensure success. For both case studies, residential sector expertise was required to carry out a market analysis, determination of units and marketing strategy. Tridel and Townhomes of Thornhill Village Ltd. were the residential components of case studies presented; and are necessary to ensure the marketability of residential units was well supported for the existing demographics.

Additionally, sector expertise for commercial retail and commercial office are necessary as well and partnerships need to be utilized. Often it is difficult to redevelop or intensify a Greyfield for mixed-use because the site's design limits the interaction between various uses such as residential, office and retail. There is a need to ensure that all uses can function independently while having coherent connectivity, but this also provides many design barriers to ensure each function accordingly. Service areas for example, need 
to be accessed by retail tenants regularly, but residential users also need complete access to underground parking. On many sites, this creates a situation where each user requires specific requirements, which cannot be accommodated based on the size of the available building footprint or design of the structure. Understanding the complexities and needs for each use is essential and sector expertise will ensure that the redevelopment functions properly and is designed to accommodate each use.

A major issue that has appeared through conducting the Greyfield case studies is length of the planning process. This can have a dramatic effect on the viability of the redevelopment because excessive costs for the developer can be accumulated. Studies, drawings, and reports need to be conducted in order for the application to be deemed complete by the City, often with several reiterations. However, these studies and drawings are an important aspect to any development; they also take an extended time to produce.

The developer needs to understand the complex nature of Greyfield redevelopment utilizing mixed-use, as it can produce substantial long-term costs. The owner of the property also needs to recognize the variability of revenues during the redevelopment, since the current tenants will not be obligated to pay their respective rents during construction. This can partially be mitigated through project phasing but construction of any kind will most 
likely lead to a reduction of profitability for tenants on site. As such, it is important to acknowledge that tenants will have concerns and accommodate them accordingly to ensure they do not terminate their lease agreement. Successful Greyfield redevelopment must produce viable commercial businesses that provide a variety of retail opportunities for the local population, ensuring that all current tenants are on board with the redevelopment is important for the development's overall longevity.

The viability of commercial units is greatly influenced by the position the developer takes based on their long-term commitment of the project. First Capital Realty for example, intends to become the property manager following the Humbertown redevelopment, which ensures that they have an interest in the types of commercial tenants that are present after construction. Rosebud Homes Development Corporation on the other hand, the developer of Olde Thornhill Village, did not have a direct interest in the commercial units on site and the variety of commercial opportunities has suffered.

The success to Greyfield redevelopment in relation to the mixed-use component is its connection between uses, the massing of the buildings onsite and automobile parking. There needs to be a strong integration of uses and coherent mixed-use opportunities. In order for this to occur, linear parks and 
parkettes should be utilized to support each use's function. These connections improve the overall viability of space and enhance efficiency. Parking is an important part of providing open space, as underground parking allows for increased landscaping, sustainability initiatives, LEED certification and passive spaces. Although there needs to be a balance between the number of underground spaces and surface parking because some commercial retail requires several convenience parking stalls for easy store access. Massing and height of the buildings of a Greyfield redevelopment is a troubling matter, as it depends on the neighbourhood context and the long-term vision for the community. The implementation of a Secondary Plan, as indicated in Olde Thornhill Village, is an important factor to guiding the development through concrete policies that require little to no interpretation by the community or the developer.

Above all, an understanding needs to be reached between the developer and the community regarding the redevelopment of the Greyfield site. Recognizing the inefficiency of space that led the retail plaza to become a Greyfield is essential. By mitigating the problems that produced the ultimate demise of the retail plaza and implementing a well-rounded redevelopment that incorporates seamless connectivity; the Greyfield redevelopment will continue to serve the community for many decades in the future. Compromise 
is a fundamental process that needs to occur on both sides, for the long-term success and stability of the community as a whole. 


\subsection{Potential Greyfield Redevelopment Site}

\subsection{9-5915 Yonge Street, Toronto}

The following case studies have provided potential proposal strategies and

site selection based on the barriers and accomplishments that became

evident. Applying this knowledge to a Greyfield site in the GTA will highlight

the necessary steps and considerations that should be taken when

redeveloping. There are a variety of sites that could have been chosen, though

the purpose of this section is to emphasize a site that has tremendous

potential based on its location, access to public transit and underutilization.

The site that has been chosen is located at 5799-5915 Yonge Street, Toronto,

as it is well suited Greyfield for redevelopment, shown in Figure 20.

Figure 20: North York Existing Greyfield- 5799-5915 Yonge Street

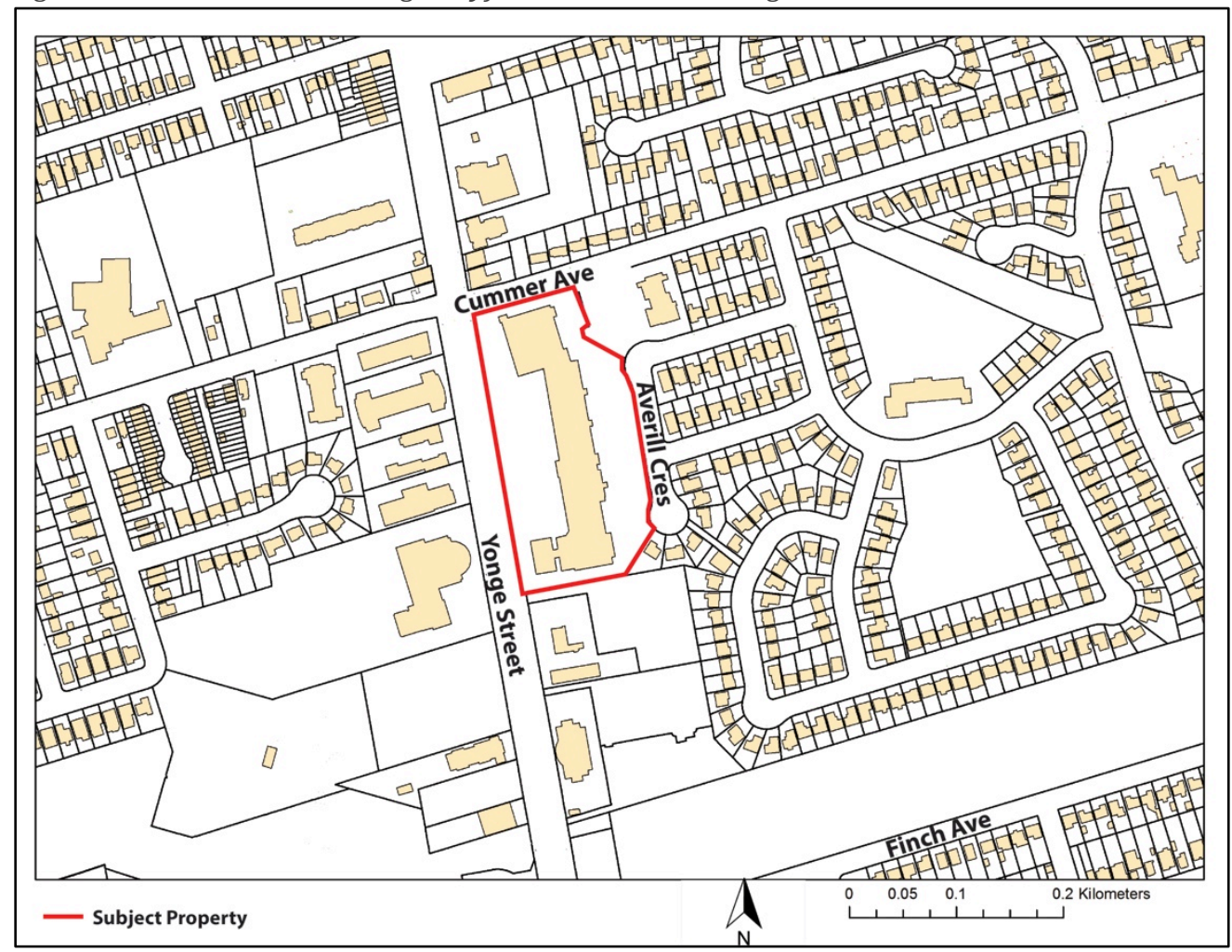




\subsection{Site Context}

The site is located in the district of North York, in the City of Toronto, near the major intersection of Yonge Street and Finch Avenue. The subject

property, shown in Figure 21, is located between Finch Avenue to the south and Cummer Avenue to the north, and fronts onto Yonge Street.

Figure 21: Figure Ground of 5799-5915 Yonge Street

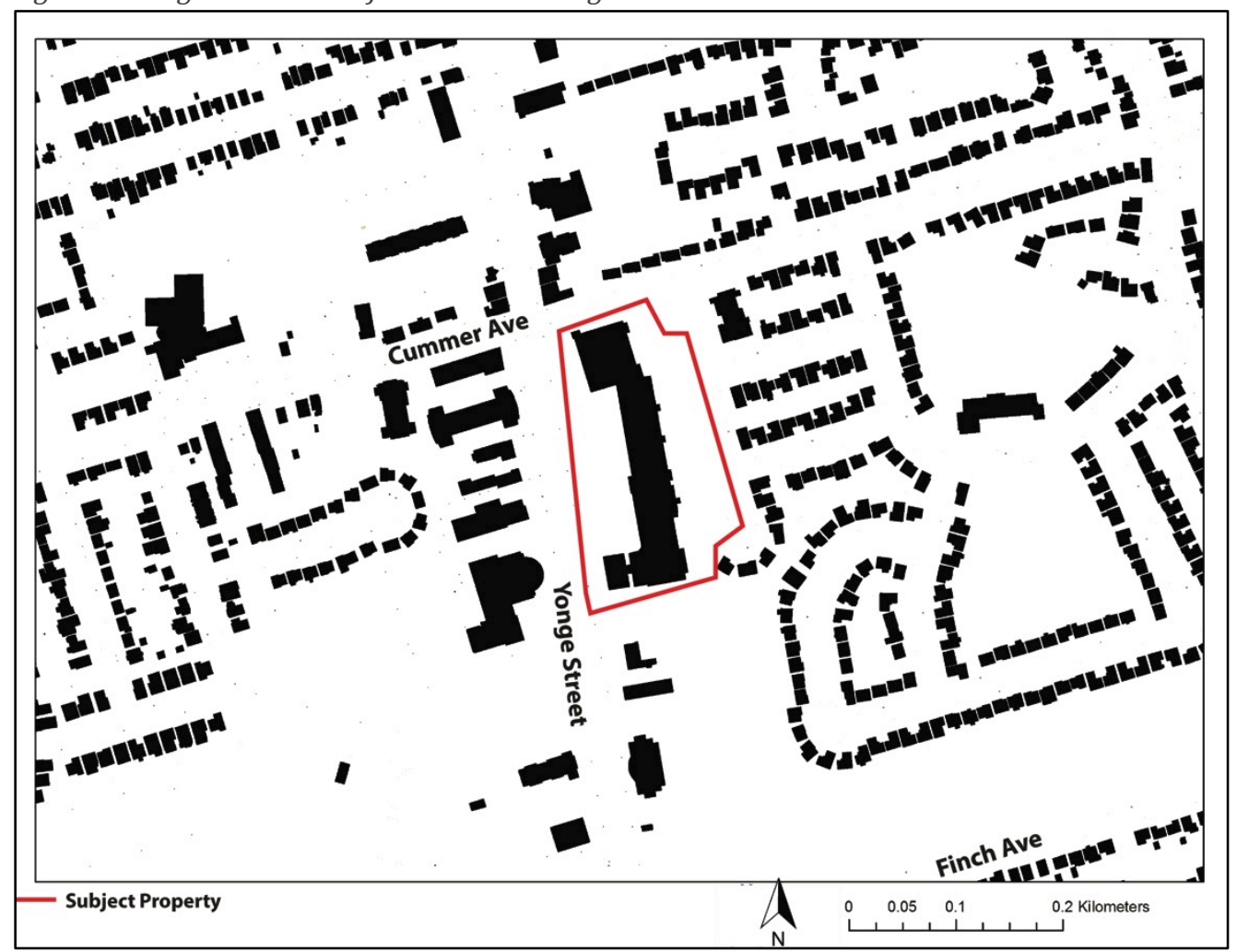

Yonge Street is considered a major arterial road in the City's road

classification system, and is not categorized as an avenue in the Avenue and Mid-Rise Building Study. The site is found just a few hundred metres away from Finch subway station, and has a bus stop at Cummer Avenue to the north, as well as one along Yonge Street. This 3 hectare retail plaza has a variety of surrounding uses such as residential, with single-family detached 
dwellings to the east and condominiums on the south and northwest.

However, commercial retail and commercial office are the predominant uses along Yonge Street. There are significant residential condominiums and office buildings to the south, due to their close proximity to the subway station, shown in Figure 22.

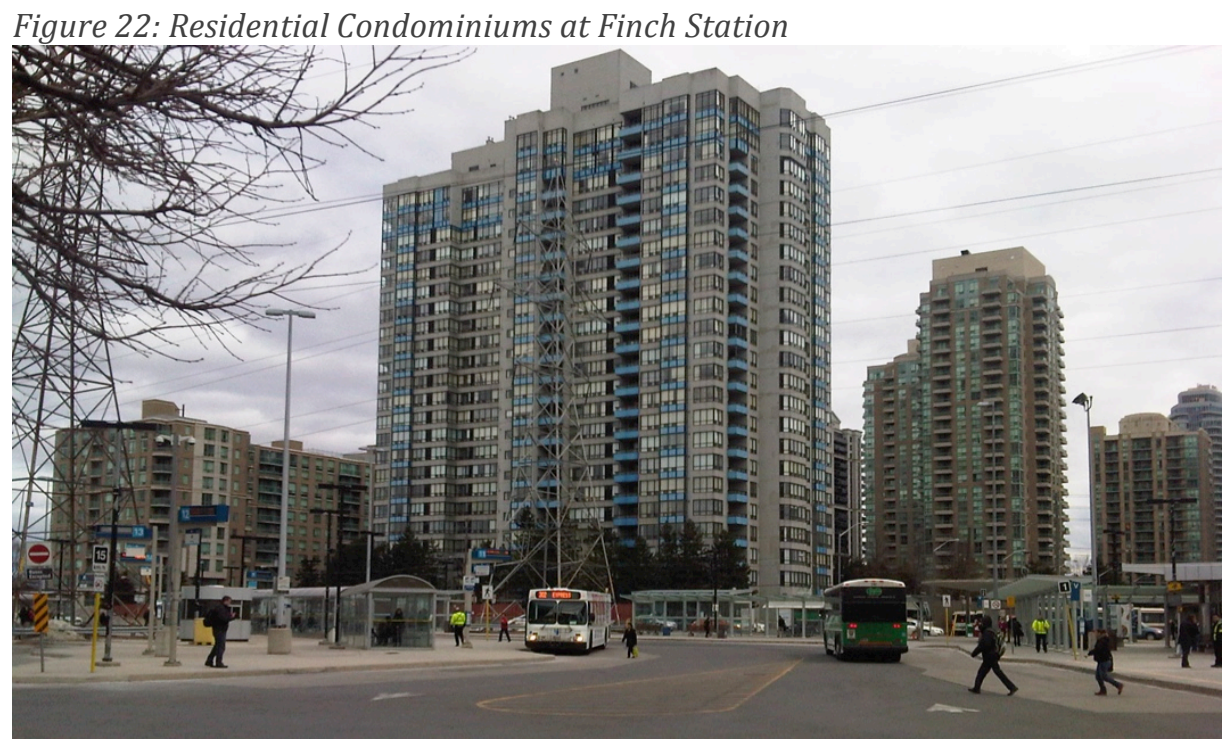

The surrounding residential and office buildings vary in height from 20storeys to 28 -storeys, and a similar height would be possible on the subject property. Although considerations need to be made regarding the adjacent properties directly to the east and west of the property, as they are low-rise developments that require proper setbacks and façade cascading. The properties on the west side of Yonge Street are a car dealership, an auto body shop, Toronto Hydro, and a 1970's apartment building. 


\subsection{Site Description}

There are a variety of commercial uses that are present onsite vary from doctors' offices, sports store, and health food store. The major anchors of the retail plaza are Food Basics, Canada Computers, and Shoppers Drugmart; and have the largest portions of floor area in the plaza. Another major component of the site is a 11-storey office building located to the south of the property, shown in Figure 23, and also dictates the residential and office uses located south of the property. This tower will be incorporated within the Greyfield redevelopment and only minor façade improvements will be completed to provide complementary appeal to the buildings proposed.

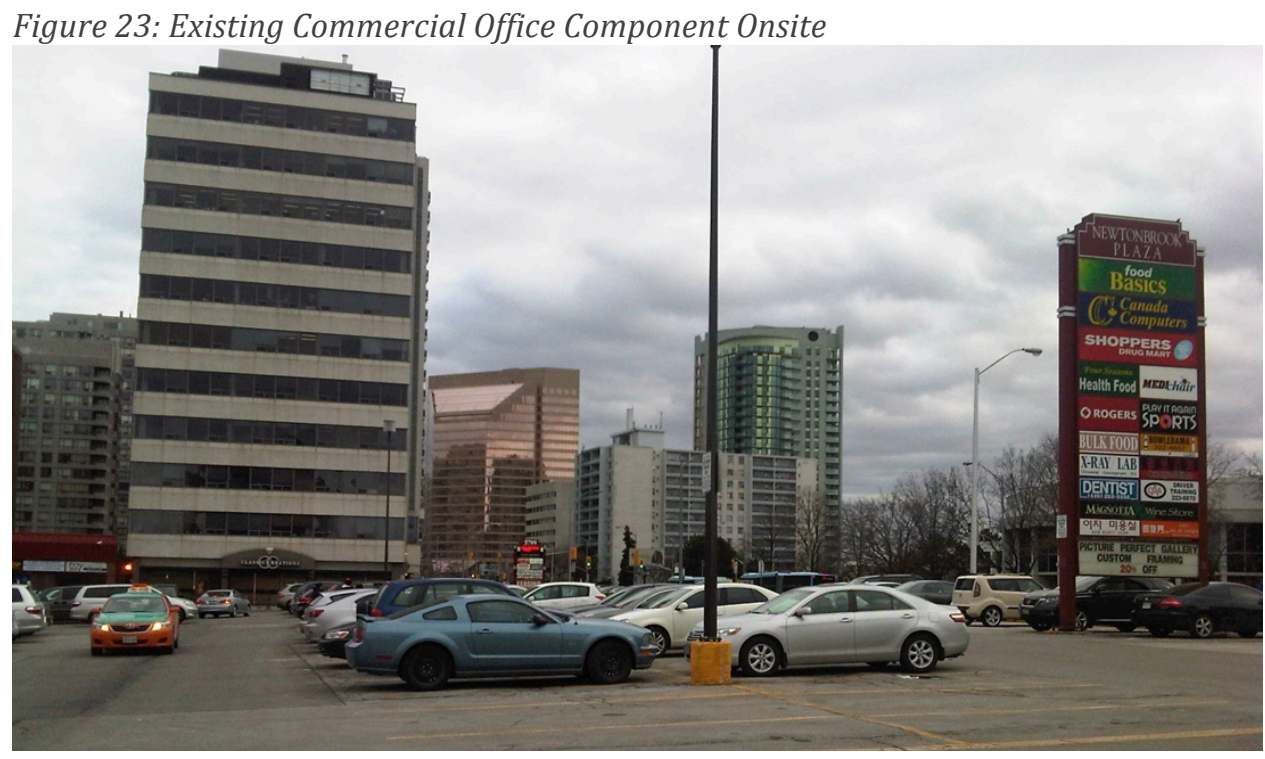

The remaining retail plaza is a low-rise structure with significant parking surrounding its entirety. There is currently no vacancy in the retail component of the plaza, although the site is a prime opportunity for redevelopment due to its size and location. There are several access points onto the site, from Yonge Street and Cummer Avenue. The main parking lot 
can be accessed from Yonge Street, and an additional lot is located on the east for servicing and employee parking. Figure 24 illustrates the diversity of retail uses on the subject property.

Figure 24: Commercial Tenants Onsite with Excessive Parking

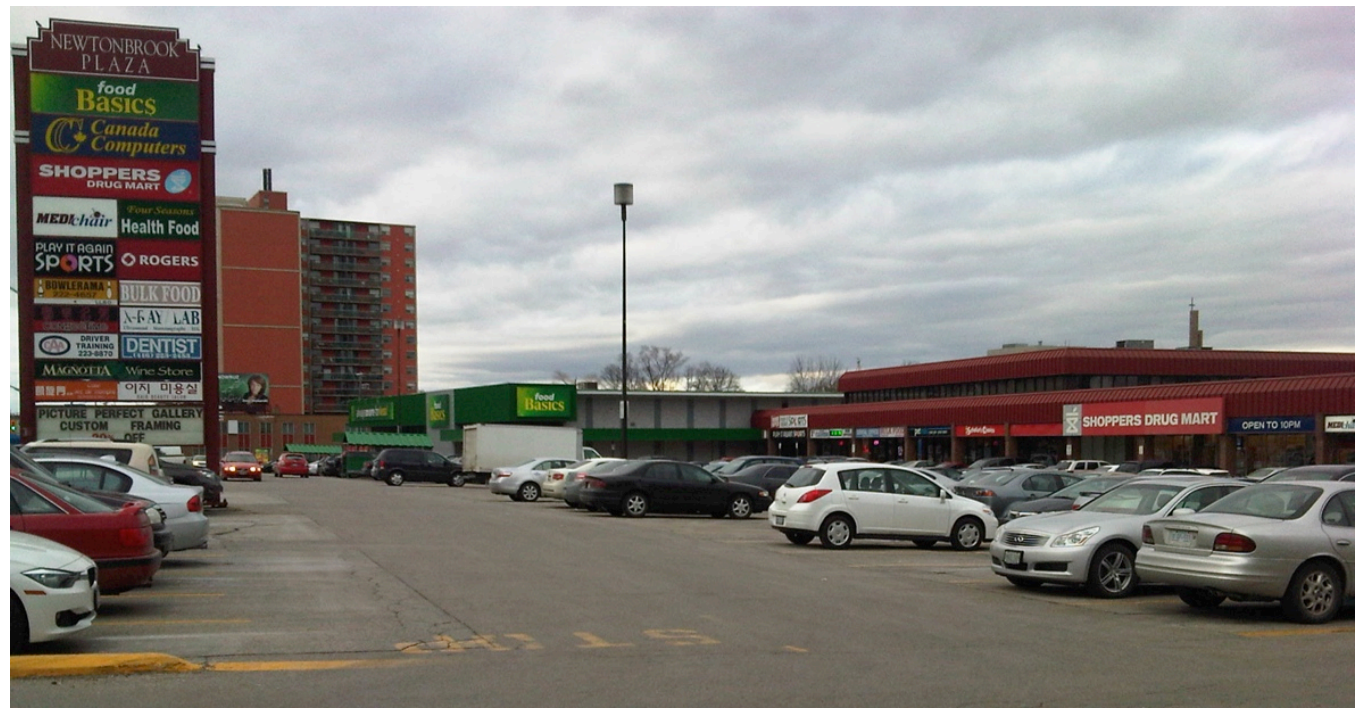

\subsection{Redevelopment Plan}

The proposal for this site is to construct three mixed-use towers with 3 -storey podiums along Yonge Street, and one midrise building. One point tower will consist of a height of 40-storeys situated in the centre and two towers will have a height of 32-storeys, while the mid-rise structure will be 6 -storeys. The towers that exist along Yonge Street will have sufficient setbacks from the arterial road and the mid-rise building will contain façade cascading to soften the transition into the low-rise housing to the east. The objective of this redevelopment is to emphasis connectivity between uses onsite and the surrounding community. This will be implemented through several linear parkettes between buildings that connect the site together with a central 
open space. It will also be facilitated through the linking of podiums, which will allow for improved internal pedestrian connections, especially in poor weather conditions. Another important aspect of this redevelopment is access and circulation of automobiles within the underground parking garage. This is an essential function to the viability of all uses onsite because the commercial retail must be easily accessible for shoppers arriving to the site by automobile. The existing anchors will enjoy larger floor areas than they currently have especially the grocery store and Shoppers Drugmart. Since Loblaws owns and operates Food Basics, the company will most likely rebrand the location to include a new Loblaws, to cater to the influx of residential units onsite. The majority of the commercial retail will be accessed from Yonge Street as at-grade retail. The second and third storeys of the podium will provide office use for the existing tenants as well as new tenants since there is a substantial increase in office Gross Floor Area. A private lane accessed from Cummer Ave, with substantial area for multiple servicing docks to accommodate all uses, will provide the site's servicing. A potential site plan design is shown in Figure 25. 


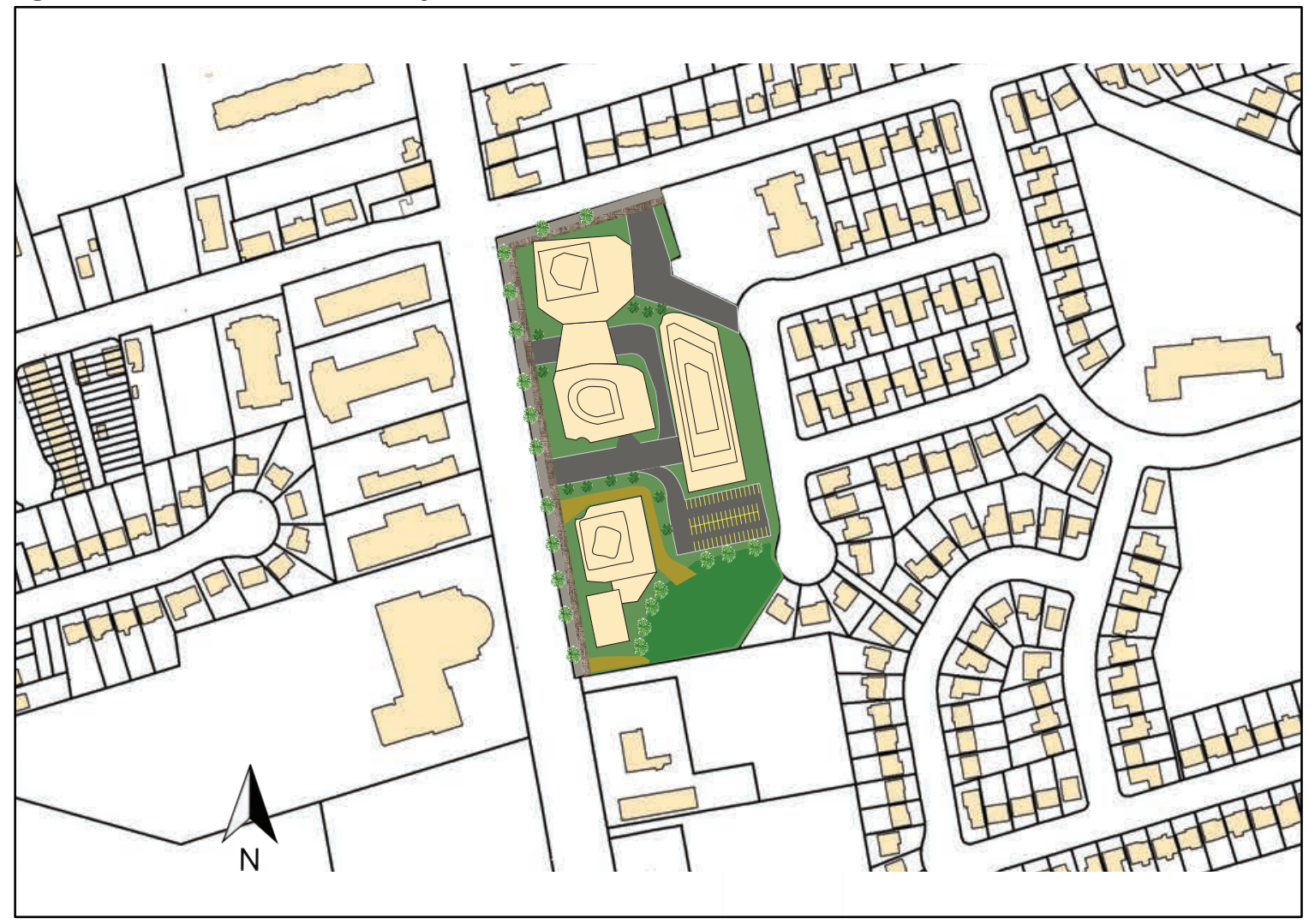

\subsection{Planning Rationale}

The location of this site is ideal for Greyfield redevelopment as it is in close proximity to Finch subway station, is located along a major arterial road, and is surrounded by mixed-use development. The large sized lot also allows for a variety of site plan designs, which could incorporate several buildings with sufficient setbacks based on the Avenues and Midrise Building Guidelines. This section of Yonge Street is not designated an avenue in the City of Toronto Official Plan or Avenues and Midrise Building study, though many of the same guidelines can be applied. Additionally, the City's Official Plan designates the site as a Mixed-use Area, which supports the introduction of 
residential proposed in this site plan design. This site falls within the North York Secondary Plan, which clearly outlines maximum building height and building setbacks. This presents an opportunity for redevelopment as the plan clearly defines urban design features, suitable traffic circulation provisions, maximum densities, and required park space. The height of each building was determined based on the maximum heights within the Secondary Plan. This ensures that shadowing concerns for the single-family detached dwellings to the east will be alleviated. The site is also surrounded by a variety of large residential buildings, which has excellent access to public transportation on the Toronto Transit Commission as well as York Region Transit. Cummer Avenue to the north of the subject property provides an essential aspect to a functioning mixed-use development, as it will be the access point to the servicing lane for deliveries. One major characteristic that the Humbertown redevelopment lacks is the ability to provide a residential drop off area. This site plan proposal presents a circular drop off space, which also provides shelter from poor weather events.

This Greyfield allows for many site plan designs as its location and attributes offer flexibility. This location indicates an immense opportunity for Greyfield redevelopment. The following model illustrates the transformation of the site and its relation to the surrounding building heights. 
Figure 26: Massing and Surrounding Heights- Facing Southwest

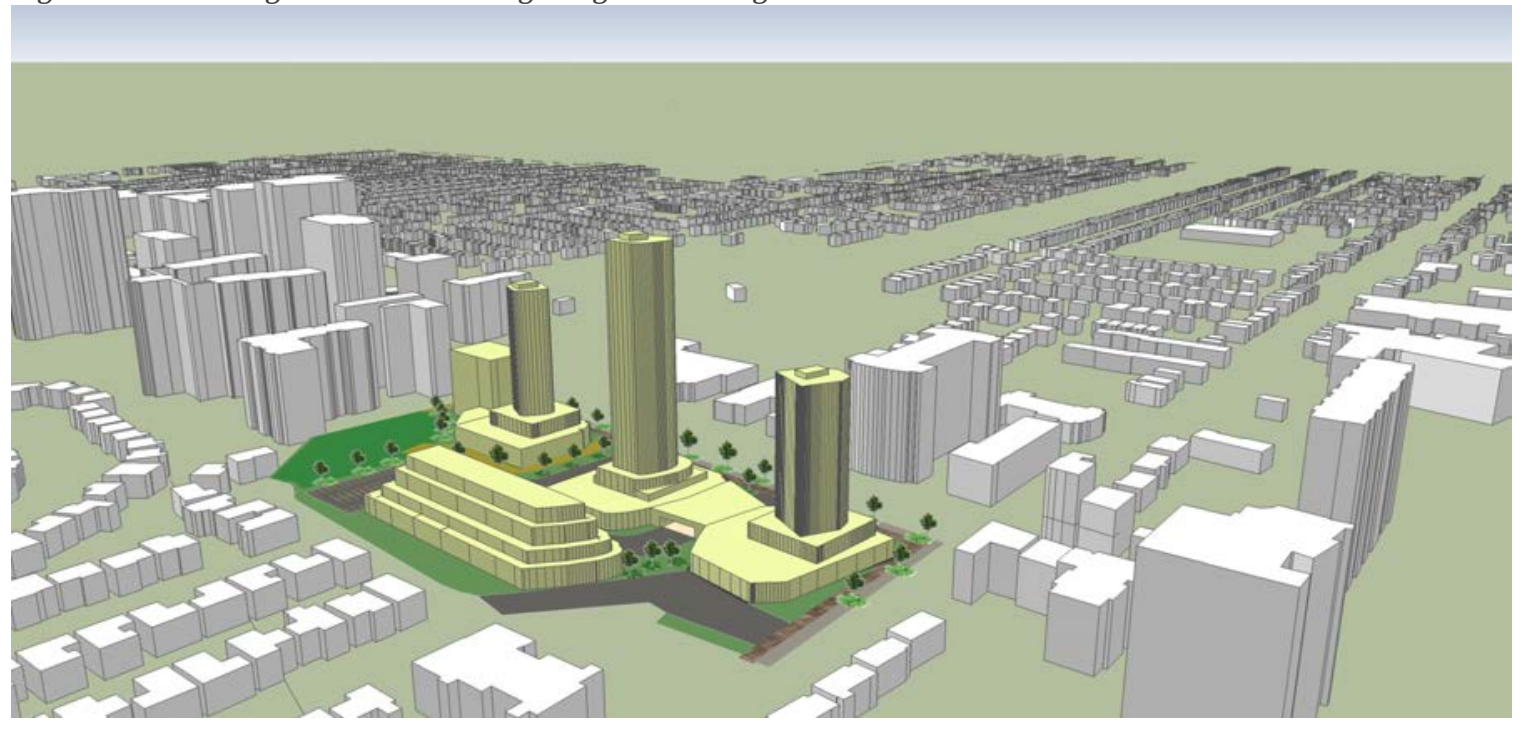

Figure 27: Yonge Street Entrance and Street Frontage- Facing South

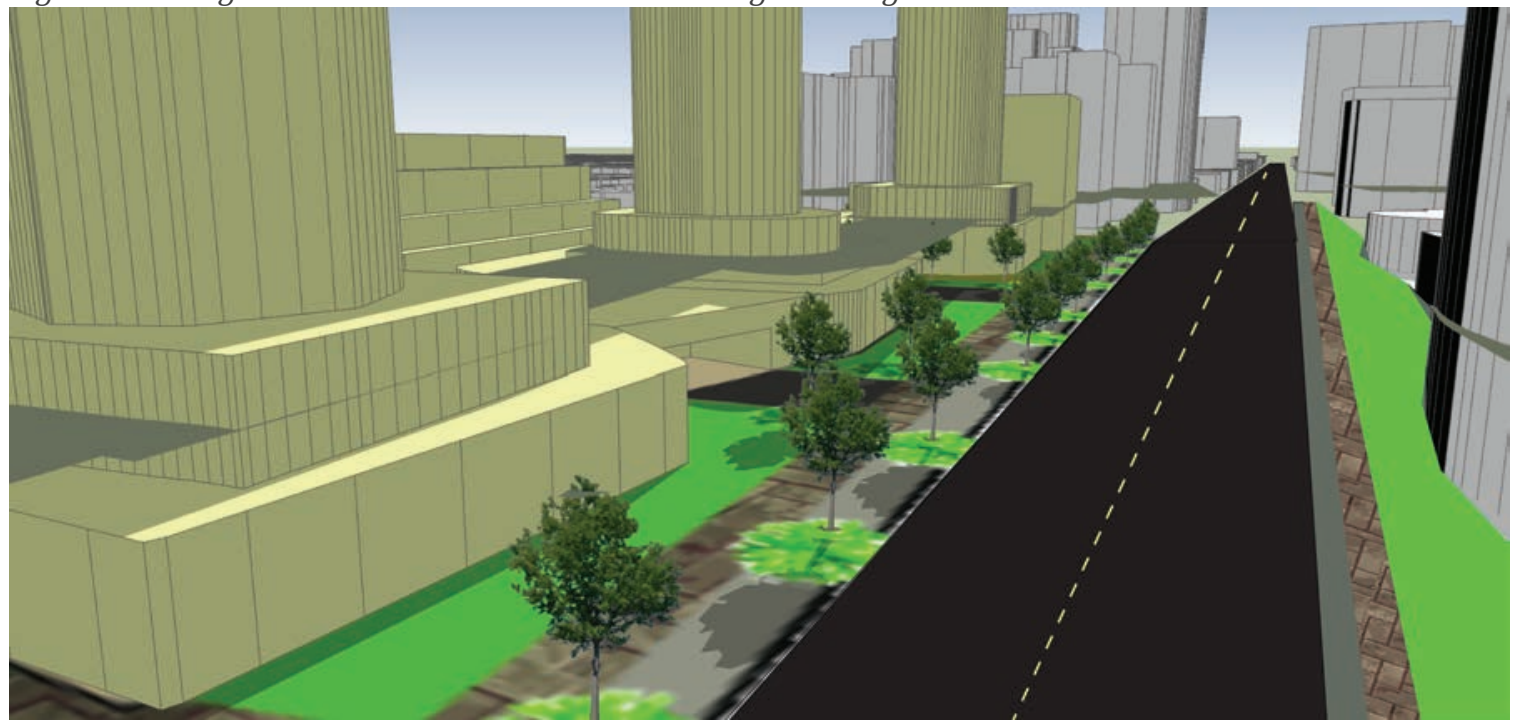


Figure 28: Illustrates Surface Parking, Park Space and Internal Traffic Circulation

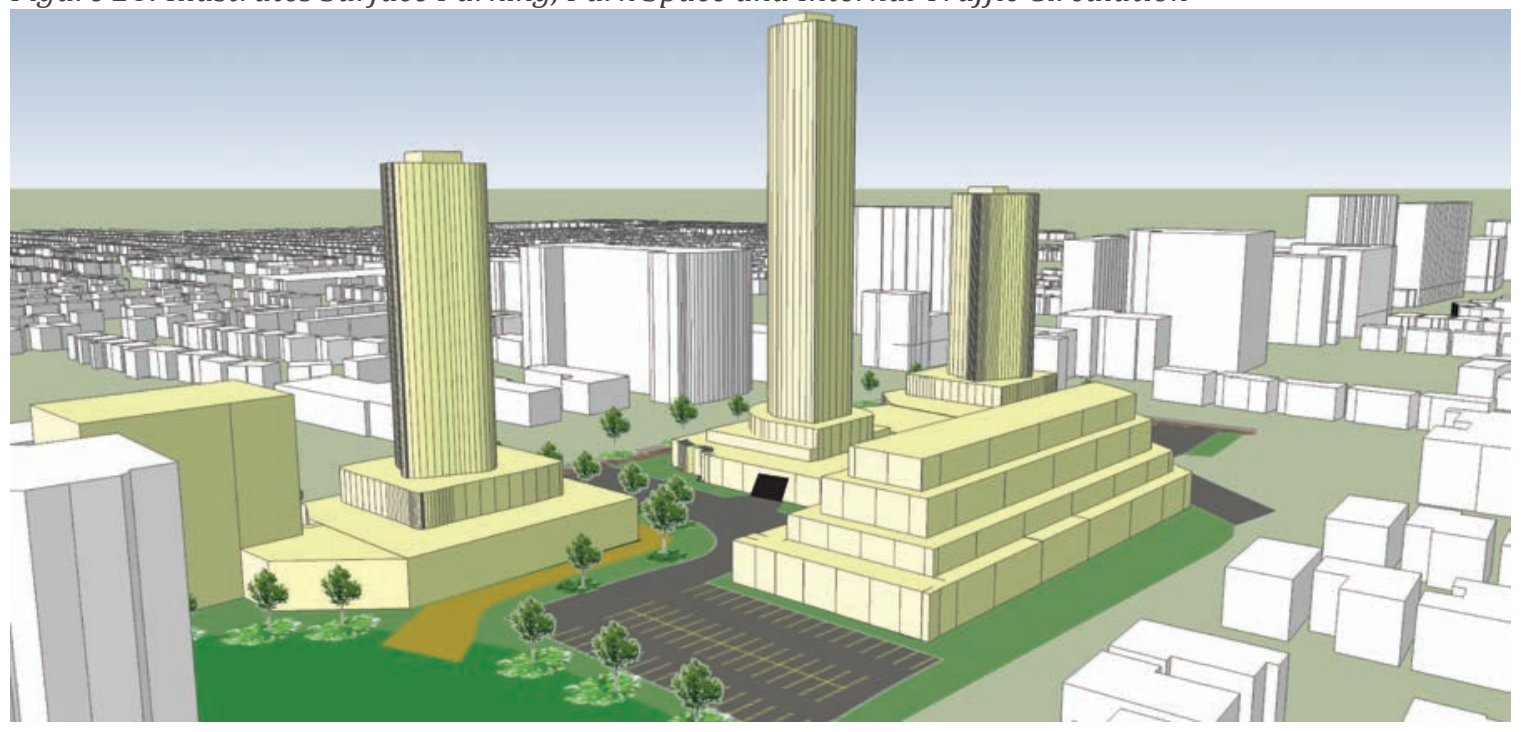

Figure 29: Height Comparison with Residential Buildings at Finch Subway Station

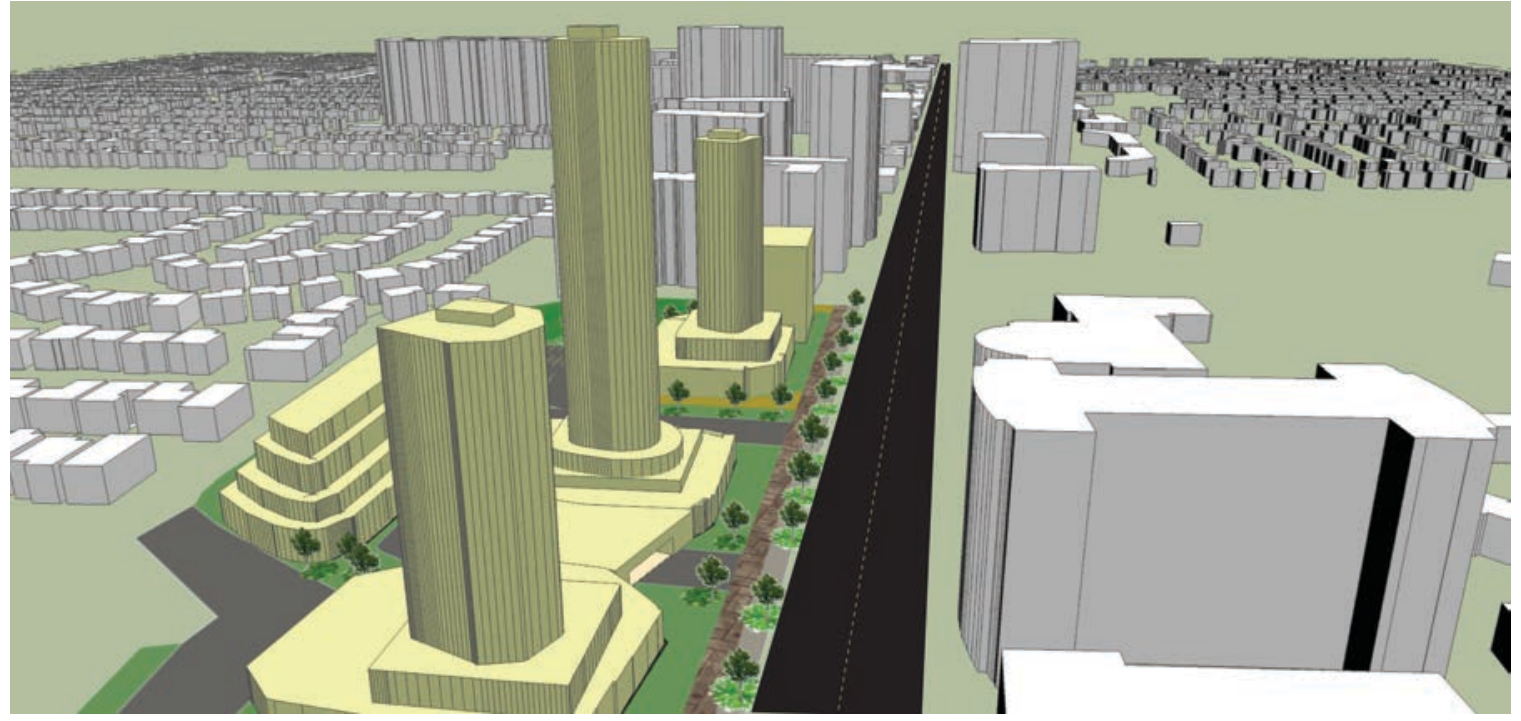




\subsection{Recommendations}

With the prediction of substantial growth to occur in the Greater Golden Horseshoe in the coming years, it is imperative that policies are implemented that will facilitate Greyfield redevelopment. There is opportunity for the Province to increase the intensification target for municipalities in the future, which will have a dramatic effect on infill redevelopment and subsequently underutilized sites such as Greyfields. Although Greyfields in Ontario do not suffer similar vacancy rates as American sites, the redevelopment potential remains. Most often the highest and best use along arterial roads is mixeduse development. There are many benefits to Greyfield redevelopment that have been identified such as creating complete communities that have integrated uses, compact design, ample open space, and transit accessibility. There is immense opportunity for Greyfield redevelopment as they represent the regeneration of urban form while utilizing existing transit and servicing infrastructure. Moreover, redevelopment strategies and site plan design are imperative to the longevity of the intensified site because without proper care the project will function improperly and will result in a future Greyfield.

The examination of the final case study of an existing Greyfield in the GTA clearly represents the redevelopment opportunity the site possesses due to its location. Applying some of the strategies that were extracted from the Olde Thornhill Village and Humbertown redevelopment, illustrates a potential site 
design and method to overcome barriers. It is essential for planners and developers alike, to understand site constraints that exist in order to maximize its redevelopment potential.

Based on the case studies and key informant interviews that were conducted, several recommendations came to fruition as a means of achieving successful Greyfield redevelopments.

Recommendation 1: A Secondary Plan needs to be implemented or initialized by the City to properly steer the redevelopment. Urban design, pedestrian oriented design, and traffic circulation provisions need to be included to ensure a comprehensive redevelopment. A Secondary Plan will also help avoid misinterpretations of Official Plan policies by the developer as well as the local community. It would provide more detailed provisions to guide redevelopment smoothly and dictate site-specific requirements such as massing, height, and setbacks.

Recommendation 2: The Canadian Mortgage and Housing Corporation needs to write a proper definition of a Canadian Greyfield to encompass the attributes of our retail market in relation to vacancy rates. Most Greyfields in Canada can be characterized as underutilized parcels of land that do not have detrimental vacancy rates, but rather large parcels of land that have 
opportunities for intensification and mixed-use. Some considerations that should be made when creating a Canadian definition include age of the structure, assessment value, Gross Floor Area, type of employment, vacancy rate, and surrounding land uses. Without a detailed definition, it is difficult to clearly identify the location of Greyfields, which leads to a lack of regulatory policies, as a framework cannot be established.

Recommendation 3: Each municipality shall include Greyfield provisions within their Official Plans to ensure that they are properly assessed as potential redevelopment sites. The long-term vision of Ontario municipalities should include Greyfield redevelopment, as they will continue to be a facet to intensification within their respective urban boundary. Utilizing Greyfield sites to meet intensification targets outlined in the Places to Grow Act, 2006 is a proactive approach for municipalities. Additionally, each municipality should highlight potential Greyfield redevelopment sites in their Official Plan to emphasize areas of intensification and highest best use.

Recommendation 4: Ontario municipalities should recognize that parkland dedication could be a major deterrent to Greyfield redevelopment as the feasibility of some sites become unprofitable for developers. A reduction of cash-in-lieu fees for parkland dedication will encourage further Greyfield redevelopment as most sites will have high appraisal values, leading to 
increased cash-in-lieu fees. Other parkland dedication provisions could be implemented to reflect larger deductions for conveyance of parkland to the City as public space.

Recommendation 5: The Province of Ontario should re-evaluate their intensification policy for large municipalities, such as the City of Toronto, to only encourage intensification where high-frequency public transportation is available. These policies shall avoid intensification on minor arterial roads, except for avenues that are designated within the municipality for densification due to their proximity to transit hubs. An important facet of mixed-use redevelopments is its ability to function with less dependence on the automobile due to the associated parking requirement onsite, which the space can be better utilized for green space or public amenities. 


\subsection{Works Cited}

\section{Primary Sources}

Personal Interview, Steve Black, Strategy Committee Member, Humber Valley Village Residents Association. March 29, 2013.

Personal Interview, Ron Blake, Planning Manager, City of Markham, March 11, 2013.

Personal Interview, Gayle Christie, Strategy Committee Member, Humber Valley Village Residents Association. March 29, 2013.

Personal Interview, Richard Morency, Strategy Committee Member, Humber Valley Village Residents Association. March 29, 2013.

Personal Interview, Cyndi Rottenburg-Walker, Senior Planner and Partner, Urban Strategies Inc., March 13, 2013

Telephone Interview, Jodi Shpigel, Vice President Development, First Capital Asset Management, March 15, 2013.

Personal Interview, Elizabeth Wimmer, Policy Planner and Urban Designer, City of Markham, March 7, 2013.

\section{Literature Sources}

Alfonzo, M. A. (2007). A mall in a former life: How converting failing malls into mixed-use neighborhoods impacts sense of community. (Ph.D., University of California, Irvine).

Bodzin, S. (2003). New Life for Old Malls. Journal of Housing and Community Development, 60(3), 51-55.

Bucher, D. (2002). Case study: Greyfields as an emerging smart growth opportunity with the potential for added synergies through a unique mix of uses. Real Estate Issues, $27(2), 46-54$.

Canadian Mortgage and Housing Corporation (CMHC) (2008). Greyfield Redevelopment Case Studies- Olde Thornhill Village.

http://www.cmhcchl.gc.ca/en/search/search_001.cfm?sec=en\&os=greyfield $\mathrm{s} \&$ radio $=$ radio\&text $=$ greyfield $\& \mathrm{x}=0 \& \mathrm{y}=0$

Canadian Mortgage and Housing Corporation (CMHC) (2009). Greyfield Redevelopment 
Case Studies- Municipal Project Initiatives: Thornhill Secondary Plan- Markham http://www.cmhcchl.gc.ca/en/search/search_001.cfm?sec=en\&os=greyfield $\mathrm{s} \&$ radio $=$ radio\&text $=$ greyfield $\& \mathrm{x}=0 \& \mathrm{y}=0 \backslash$

Chilton, K. (Undated). Greyfields: The New Horizon for Infill and Higher Density Regeneration, Practice Guide \#6, EPA Region 4. Published by Center for Environmental Policy and Management, University of Louisville. Undated.

City of Toronto. (2010). Zoning By-law 1156-2010. Performance Standards.

Congress for the New Urbanism (CNU) (2005). Malls into Mainstreets.

De Sousa, C. (2002). Measuring the Public Costs and Benefits of Brownfield Versus Greenfield Development In the Greater Toronto Area, Environment and Planning B: Planning and Design, Volume 29.

De Sousa, C. (2006). Urban Brownfields Redevelopment in Canada: the Role of Local Government, The Canadian Geographer, Volume 50, No. 3.

Gilder-Busatti, A. (2007). Quantifying the use of New Urbanism and Smart Growth Principles in the Redevelopment of Greyfield Sites in Central Maryland. (M.C.R.P., Morgan State University).

Gomez-Insausti, R., Erguden, T. \& K. Jones. (2000). Greyfield Shopping Centres: Myth or Reality? Toronto, Ont.: Centre for the Study of Commercial Activity, Ryerson University

Hernández, T. (2009). In Erguden T., Svindal M. and Rogers Media. (Eds.), Retail Store Vacancy in the GTA : 2005 to 2009. Toronto, Ont.: Centre for the Study of Commercial Activity, Ryerson University.

Hernández, T. (2011). In Ryerson University. Centre for the Study of Commercial Activity. (Ed.), Power Centre Vacancy in Canada: 2010. Toronto, Ont.: Centre for the Study of Commercial Activity, Ryerson University.

Hernandez, T., Helik, J., \& P. Moore. (2006). The Changing Character of Retail Strips in the City of Toronto: 1996- 2005. Toronto, Ont.: Centre for the Study of Commercial Activity, Ryerson University.

Kures, M. (2003, May). Greyfields and Ghostboxes - Evolving Real Estate Challenges, Let's Talk Business Newsletter, Center for Economic Development, University of WisconsinExtension, 81. 
Mandel, C. (2005, Aug 20). Building over Parkades and Moving into Malls: Times Colonist.

McKay, D. (2006). Redeveloping Greyfields in the Greater Toronto Area. Current Issues Paper. Department of Geography, University of Toronto.

Planning Advisory Service Report (2009). Grayfield Redevelopment Model Approaches. (556), 217-223.

PricewaterhouseCoopers (PWC) (2001, Jan.). Greyfield Regional Mall Study.

Province of Ontario (2006). Places to Grow: Growth Plan for the Greater Golden Horseshoe (2006). Minister of Infrastructure, Places to Grow Act.

Shaw, H. (2012, Apr. 27). Canada's Shopping Hordes Attract American Retailers. Times Colonist.

Sobel, L. S. (2002). In Greenberg E., Bodzin S. and Congress for the New Urbanism. (Eds.), Greyfields into goldfields: Dead malls become living neighborhoods. San Francisco, Calif.: Congress for the New Urbanism.

Sochar, B. H. (2008). Shining the Light on Greyfields: A Wal-mart Case Study on Preventing Abandonment of Big Box Stores Through Land use Regulations. Albany Law Review, 71(2), 697-730.

Smart Growth Network. (2001). What is Smart Growth? Washington, D.C.: United States Environmental Protection Agency.

Statistics Canada. (2007). Focus on Geography Series, 2006 Census. Statistics Canada Catalogue no. 98. Ottawa, Ontario. Analytical products, 2006 Census. Last updated October 24, 2012.

Statistics Canada. (2012a). Focus on Geography Series, 2011 Census. Statistics Canada Catalogue no. 98-310-XWE2011004. Ottawa, Ontario. Analytical products, 2011 Census. Last updated October 24, 2012.

Statistics Canada. (2012b). Toronto, Ontario (Code 535) and Ontario (Code 35) (table). Census Profile. 2011 Census. Statistics Canada Catalogue no. 98-316-XWE. Ottawa. Released October 24, 2012. Accessed February 10, 2013.

Urban Strategies Inc. (2012, Dec.). Planning Rationale. 270 The Kingsway, Humbertown Redevelopment. 
Vasilyan, T. (2011). Repurposing suburbia. (M.Arch., Carleton University (Canada).

Webb, M. (2003). Reviving dead malls. Architecture, 92(4), 41-42.

\section{Photo Sources}

Kohn Architects (2004). Site Plan, 300 John Street, Markham

Urban Strategies Inc. (2012, Jan.). Planning Rationale. 270 The Kingsway, Humbertown Redevelopment. 